\title{
Matematik Öğretmenlerinin Matematiksel Görev Oluşturma Durumlarının İncelenmesi
}

\author{
Semra POLAT \\ Muş Alparslan Üniversitesi \\ s.polat@alparslan.edu.tr \\ Yüksel DEDE \\ Gazi Üniversitesi \\ ydede@gazi.edu.tr
}

Gönderilme Tarihi: 03/05/2020

Kabul Tarihi: $10 / 07 / 2020$

Yayınlanma Tarihi: 29/07/2020

DOI: $\underline{10.30855 / \text { gjes.2020.06.02.003 }}$

\begin{tabular}{|c|c|}
\hline Makale Bilgileri & ÖZET \\
\hline $\begin{array}{l}\text { Anahtar } \\
\text { Kelimeler: }\end{array}$ & $\begin{array}{l}\text { Bu çalışmanın amacı, ortaokul matematik öğretmenlerinin farklı } \\
\text { matematiksel görev oluşturma durumlarını ve bu görevleri }\end{array}$ \\
\hline $\begin{array}{l}\text { Matematik } \\
\text { öğretmenleri, } \\
\text { Matematiksel } \\
\text { görev, } \\
\text { Matematiksel } \\
\text { görev oluşturma, } \\
\text { Tercih edilen } \\
\text { konular }\end{array}$ & $\begin{array}{l}\text { oluştururken kullandıkları matematiksel konuları belirlemektir. Bu } \\
\text { kapsamda bu çalışma, nitel araştırma yöntemlerinden tekli durum } \\
\text { çalışması deseni kullanılarak yürütülmüştür. Çalışma, 2019-2020 } \\
\text { eğitim-öğretim yılı bahar yarıyılında Doğu Anadolu'daki bir ilin } \\
\text { merkez ve ilçelerinde bulunan resmi ortaokullarda görev yapan ve } \\
\text { kolay ulaşılabilir örnekleme yöntemi ile belirlenen } 18 \text { matematik } \\
\text { öğretmeniyle gerçekleştirilmiştir. Veriler, açık uçlu sorulardan oluşan } \\
\text { bir yazılı görüş formu aracılığıyla toplanmış ve anlamsal içerik analizi } \\
\text { yöntemi ile analiz edilmiştir. Çalışmanın bir sonucu, matematik } \\
\text { öğretmenlerinin en fazla bağlama dayalı görevler oluşturmaya } \\
\text { çalıştıklarını ortaya koymuştur. Ayrıca, bu görevlerin oluşturulmasında } \\
\text { kullanılan matematiksel konuların görev türüne göre farklılaştı̆̆ da } \\
\text { belirlenmiştir. Ek olarak, ileri araştırmalar için bazı öneriler de } \\
\text { yapılmıştır. }\end{array}$ \\
\hline
\end{tabular}

Polat, S., \& Dede, Y. (2020). Matematik öğretmenlerinin matematiksel görev oluşturma durumlarının incelenmesi. Gazi Ĕ̆itim Bilimleri Dergisi, 6(2), 210-239. DOI: https://dx.doi.org/110.30855/gjes.2020.06.02.003

Dergi Web Sayfası: http://dergipark.gov.tr/gebd 


\section{Examination of Mathematics Teachers' Mathematical Task Design Situations}

\begin{tabular}{|c|c|}
\hline Article Info & ABSTRACT \\
\hline $\begin{array}{l}\text { Keywords: } \\
\text { Mathematics } \\
\text { teachers, } \\
\text { Mathematics } \\
\text { task, } \\
\text { Designing } \\
\text { mathematics task, } \\
\text { Preferred } \\
\text { subjects }\end{array}$ & $\begin{array}{l}\text { The aim of this study is to determine the situations of middle school } \\
\text { mathematics teachers to design different types of mathematical tasks } \\
\text { and their used mathematical subjects when designing these tasks. In this } \\
\text { context, this study was conducted using a single case study method } \\
\text { from qualitative research methods. The study was carried out in the } \\
\text { spring semester of the } 2019-2020 \text { academic year with } 18 \text { mathematics } \\
\text { teachers working in state middle schools in the central and districts of a } \\
\text { province in eastern Anatolia and determined by convenience sampling } \\
\text { method. The data were gathered using a written form of open-ended } \\
\text { questions and analyzed using semantic content analysis. One result of } \\
\text { the study revealed that mathematics teachers tried to design the most } \\
\text { contextual tasks. It was also determined that the mathematical subjects } \\
\text { used in the design of these tasks differ according to the task type. In } \\
\text { addition, some suggestions have been made for further research. }\end{array}$ \\
\hline
\end{tabular}

\section{GİRIŞ̧}

Matematik eğitimindeki süregelen tartışmalar incelendiğinde, çoğunun öğrencilerin kavramsal anlayışlarındaki sınırlamaların yanı sıra matematikteki düşünme, akıl yürütme ve problem çözme becerileri üzerine odaklandığı görülmektedir (Hiebert \& Carpenter, 1992; Lindquist \& Kouba, 1989; National Research Council, 1989). Bu tartışmalara cevap olarak, Amerikan Ulusal Matematik Öğretmenleri Konseyi [NCTM], matematiğin öğretim ortam ve süreçlerinin etkililiğini ve verimliliğini arttırmak için müfredat, değerlendirme ve öğretim uygulamalarına vb. yönelik reform niteliğinde önemli eserler yayımlamıştır (bkz. NCTM, 1989, 1991, 1995). NCTM'nin bu reform çabalarının altında ise öğrencilerin matematiğe yönelik anlayışlarını geliştirme, matematik yapmalarını ve düşünmelerini destekleme ve iyi bir matematiksel eğilime sahip olmalarını sağlama yatmaktadır (Henningsen ve Stein,1997). Matematiksel eğilime sahip olmak ise matematiksel yapıları ve bunların altında yatan ilişkileri anlamak için örüntüleri arama ve keşfetmeyi, problemleri formüle etmek ve çözmek için mevcut kaynakları etkin ve uygun bir şekilde kullanmayı içermektedir. Aynı zamanda bu eğilim, matematiksel fikirleri anlamlandırma, tahmin etme, genelleme, gerekçelendirme, iletişim kurma ve matematiksel sonuçların mantıklı olup olmadığına karar vermeyle de ilişkilidir (Schoenfeld, 1992). Bu bağlamda, öğrenciler bu matematiksel eğilime hangi düzeyde ve oranda sahip olurlarsa, matematiğin öğretim ortam ve süreçlerinde zengin ve değerli matematiksel görevlere (task) dayandırılan, dinamik matematiksel etkinliklerin yer alma sıklığının da o düzey ve oranda olabileceği belirtilmektedir (bkz. NCTM, 1991; Schoenfeld, 1994). 


\section{Görev ve Matematiksel Görev}

Görev kavramı, bir nesne veya bir kimsenin yaptığı iş; iş görme yetisi, fonksiyon olarak tanımlanmaktadır (Türk Dil Kurumu [TDK], 2011). İlgili literatür incelendiğinde, görev kavramının ne olduğuna yönelik tam olarak bir uzlaşı olmasa da, görev kavramı genel olarak önceden bilinen bir algoritmayı uygulamayı gerektiren ve basit belirsizlik/belirsizlikler içeren durum/durumlardan ziyade gerçekten sorunlu ve karmaşık durum/durumlar içeren problemler olarak tanımlanmaktadır (Stein, Grover ve Henningsen, 1996). Benzer şekilde Brousseau (1997) da görev kavramı, öğrencilerin kavramsal ve işlemsel becerilerini geliştiren, akıl yürütme becerilerini destekleyen ve onları daha fazla düşünmeye yönlendiren her türlü problem veya sorular olarak ele almıştır. Sáiz ve Figueras (2009) da, görev kavramını öğrencilere verilen her türlü problem veya soru olarak değerlendirmiştir. Bir görevin ne olduğuna yönelik bu yaklaşımlara göre, görevler genel olarak birden fazla çözüm stratejisine sahip olma, farklı şekillerde temsil edilebilme, öğrencileri fikirlerini açıklamaları ve gerekçelendirme yapmaları konusunda teşvik etme vb. özellikleri içermektedir (Stein, Grover vd., 1996). Diğer taraftan, matematiksel görevler ise öğretmenlerin hedeflerinden, konu ve kavram bilgilerinden ve öğrencilerin hazırbulunuşluk ve anlayışlarından etkilenen (veya onları etkileyen) öğretim materyalleri olarak ifade edilmektedir (bkz. Sullivan, Clarke, ve Clarke, 2012). Zira matematiksel görevlerin ve onlarla ilişkilendirilen faaliyetlerin, öğretim ortam ve süreçlerindeki etkileşimlerin (öğrenci-öğretmen, öğrenci-öğrenci vb.) temelini oluşturduğuna yönelik ifadelere literatürde sıklıkla yer verilmektedir (bkz. Sullivan, Clarke, Clarke ve O'Shea, 2009) Ayrıca matematiksel görevler, öğrencilere kavramsal düşünmeleri için zengin fırsatlar sağlarken aynı zamanda kavramlar arasındaki ilişkileri kavrama noktasında da onları teşvik ederler (Stein ve Smith, 1998). Zira matematiksel görevler, öğrencilerin matematiksel kavramların, süreçlerin ve ilişkilerin doğasına ilişkin daha derin bir anlayış kazanmalarının yanında belirli bir matematiksel fikre ve kavrama odaklanmalarını da sağlarlar (Stein, Grover vd., 1996; Stein, Smith, Henningsen ve Silver, 2000). Zaten Anthony ve Walshaw (2009) da, matematiksel görevlerin öğrencileri zorladığını, matematiksel bir kavrama odaklandırdığını ve onlara matematiğin yapısı ile problem çözme stratejileri hakkında zengin bilgiler verdiğini belirtmiştir. Bu durum ise öğrencilerin matematiğin ne ifade ettiğine ve matematik yapmanın ne olduğuna yönelik doğru ve derin bir anlayış kazanmalarına yol açar (Hiebert ve Wearne, 1993; NCTM, 1991; Marx ve Walsh, 1988; Zaslavsky, 2005). Üstelik öğrenci performanslarının değerlendirilmesinde de, matematiksel konu veya kavramların anlamlarını irdeleyen ve matematiksel işlemlerin doğru olarak yapılmasını gerektiren görevlerin kullanımının önemine vurgu yapılmaktadır (Stein ve Lane, 1996). Ayrıca bu tarz görevler ve sınıf içi söylemler, öğrenme ve öğretme arasındaki ilişkide bir çeşit arabulucu görevi de oynarlar. Bu nedenle öğretmenler, öğretimlerinde daha üst düzey matematiksel görevlere yer vermelidir. Bu durum ise öğrencilerin bu tarz görevlere, kavrama/konuya ilişkin 
fikirlerini açı̆̆a çıkaracak şekilde daha uzun cevaplar vermelerine ve matematiksel değerlendirmelerde de daha yüksek performans göstermelerini sağlayabilir (Hiebert ve Wearne, 1993). Bu nedenle birçok araştırma, öğrenci öğrenmesini artırmak için etkinlikleri, sorgulama yöntemlerini ve problem durumlarını içeren matematiksel görevlerin oluşturulması ve uygulanması üzerine odaklanmaktadır (ör., Smith ve Stein, 1998; Swan, 2005; Tzur, Zaslavsky ve Sullivan, 2008; Sullivan vd., 2012). Örneğin, Swan (2005), nesneleri sinıflandırma, çoklu temsilleri yorumlama, matematiksel ifadeleri değerlendirme, problem kurma, akıl yürütme ve çözümleri analiz etme vb. boyutlarını kullanarak matematiksel görevlerin oluşturulmasını ve uygulanmasını tavsiye etmiştir. Bu bağlamda Sullivan ve ark. (2012) de, öğretmenlerin derslerinde kullanabilecekleri 3 matematiksel görev türü önermiştir. Bu matematiksel görev türlerine ilişkin kısa açıklamalar aşağıdadır:

Tür 1 (Model): Temel bir matematik konusu veya kavramına yönelik açıklama, somut/soyut araç, temsil ve modellerin tanıtımını veya kullanımını içeren görev çeşididir. Öğrencilerin kesirleri karşılaştırmasını, kesir denkliklerini belirlemesini ve kesirler içeren denklemleri çözmesi için kesir bloklarının, duvarlarının, şeritlerinin vb. kullanımını gerektiren görevler bu görev türüne örnek olarak verilebilir.

Tür 2 (Bağlamsal): Gerçek dünya bağlamlarına gömülü problem durumları içerisinde matematiğin ele alınmasını sağlayan ve aynı zamanda öğrencilerin matematiğe yönelik ilgilerini çekmeyi ve motivasyonlarını arttırmayı hedefleyen görev türüdür. Bağlama dayalı görevlerin içerdiği veriler, bir grafik, kısa bir haber metni veya bir hikâyede bulunabilir (Van de Walle, Karp, Bay-Williams, Wray ve Brown, 2019). Bir görevin, bağlamsal bir görev olması için günlük yaşama dayalı bir duruma/durumlara sahip olması ve bu durumun/durumların da öğrencileri verilen görevi tamamlamaya yönlendirecek gerekçe/gerekçeler sunması gerekmektedir (Benckert, 1997). Buna göre örneğin, “Usain Bolt, 100 metreyi 9.7 saniyede koşmaktadır. Siz ne kadar zamanda koşarsınız?" (Sullivan vd., 2012, s. 50) sorusu bu görev türü kapsamında değerlendirebilir.

Tür 3 (Açı uçlu): Öğrencilerin özel bir matematiksel içeriği keşfetmelerini ve bu içeriğe yönelik olası farklı çözüm yollarını ve çoklu doğru cevapları araştırmalarını sağlamayı amaçlayan görev türüdür. Örneğin, "Çevresi $20 \mathrm{~cm}$ olan bir dikdörtgenin alanı kaç $\mathrm{cm}^{2}$ dir?" (Sullivan vd., 2012, s. 65) sorusu bu görev türü içinde ele alınabilir.

Yukarıda belirtilen matematiksel görev türlerinin öğretim ortam ve süreçlerinde etkili bir biçimde kullanılabilmesi için ise devreye öğretmen bilgisi, kararları ve davranışları girmektedir. Zira öğretmen bilgisi, kararları ve davranışları, öğrencilerin zor matematiksel görevlere katılımının niteliğini ve kapsamını etkilemektedir (bkz. Silver ve Herbst, 2008). 


\section{Matematik Öğretmenleri ve Matematiksel Görevler}

Matematiksel görevler, öğretmenler ve öğrenciler arasındaki etkileşimi sağlayan en önemli araçlardan biridir (Krainer, 1993) ve sınıf içi normlar, öğretmenlerin öğretim alışkanlıkları ve eğilimleri, öğrencilerin öğrenme alışkanlıkları ve eğilimleri vb. birçok faktörler dikkate alınarak oluşturulur (Sullivan vd., 2012). Dolayısıyla öğretmen yeterlikleri, genelde etkili bir matematik öğretiminin yapılması özelde de etkili matematiksel görevlerin oluşturulması için bu noktada devreye girmektedir (Clarke, 1997; Clarke ve Roche, 2010; Fullan, 2001; Yun-peng, Chi-chung ve Ngai-ying, 2006). Ayrıca öğretmen yeterlik ve eylemleri, öğrencilerin özellikle zor matematiksel görevlere katılımının niteliğini ve kapsamını da etkilemektedir (Silver ve Herbst, 2008). Bu nedenle NCTM (1991), öğrencilerin matematiksel anlayışları, yeterlikleri, ilgi alanları ve eğilimlerinin gelişmesi için fırsatlar sağlayan değerli görev ve materyallerin seçimi ve geliştirilmesi noktasında öğretmenlerin merkezi konumda olduklarını ifade etmektedir. Benzer şekilde Milli Eğitim Bakanlığ1 [MEB] $(2005 ; 2018)$ da, matematik öğretmenlerinden öğrencilerinin düşünme biçimlerini şekillendiren ve güdüleyen görevler (hatırlama, değerlendirme, akıl yürütme ve yaratıcı düşünmeyi içeren) oluşturmalarını ve derslerinde bu tarz görevleri kullanmalarını tavsiye etmektedir. Bu durumda öğretmenler, matematiksel görevlere dayalı sınıf uygulamalarının etkili biçimde gerçekleştirilmesinin de en önemli öğesi konumundadır. Dolayısıyla, öğretmenlerin matematiksel görev türlerine ilişkin bilinçli bir farkındalıklarının olması etkili bir öğretim için gereklidir. Aksi bir durumda, öğretmenler öğrencilerin farklı matematiksel becerilerini geliştirmek için kullanılması gereken farklı matematiksel görev türlerini belirlemede ve kullanmada başarısız olurlar ve bu görev türleri aracılığıyla öğrencilerin zihinsel yapılarının çeşitli yönlerini geliştirmeleri de oldukça zorlaşır (Yeo, 2007). Zira matematiksel görevler, matematik yapma ilkelerinin ve koşullarının neler olduğunu öğrencilere en iyi biçimde aktaran önemli mesajlardır (Hiebert ve Wearne, 1993; Marx ve Walsh, 1988; NCTM, 1991; Zaslavsky, 2005).

\section{Araştırmanın Amacı ve Önemi}

Bu çalışmanın öncelikli amacı, matematik öğretmenlerinin farklı matematiksel görev türleri oluşturma durumlarını incelemektir. Ayrıca, bu görevleri oluştururken tercih ettikleri matematiksel konu ve kavramların neler olduğu da araştırılmıştır. Zira öğrenme ortam ve süreçlerinde öğrencilere verilen soru ve görevlerin genellikle daha önce öğrenilmiş bilgilerin tekrarı ve pekiştirilmesine yönelik olduğu, başka bir ifadeyle daha çok alıştırma düzeyinde kaldığı belirtilmektedir (Van de Walle vd., 2019). Öğretim ortamlarında ezbere veya belli algoritmalara dayalı soruların kullanımı ise öğrencilerin kavramsal öğrenmelerini engelleyebilir ve matematiksel düşünme becerilerini sınırlandırıp, mekanik bir forma indirgeyebilir (Henningsen ve Stein, 1997). Halbuki sınıflarda, soru ve görevlerin farklı işlevlerinin olduğunun 
unutulmaması ve bu işlevler dikkate alınarak görevlerin oluşturulması, planlanması ve uygulanması gerekmektedir (Van de Walle vd., 2019). Üstelik, öğrenciler de ancak kendilerine verilen matematiksel görevlerin türleri ve içerikleri doğrultusunda bir matematiksel anlayış geliştirebilirler (Hiebert vd., 1997). Zaten NCTM (2000) de, iyi seçilmiş görevlerin öğrencilerin matematiği öğrenmeye yönelik ilgilerini artırabileceğini belirtmektedir. Bu nedenle, sınıflarda düşük düzeyde düşünmeyi gerektiren görevlerden ziyade daha üst düzey düşünmeyi gerektiren görevlerin seçilmesi ve uygulanması önerilmektedir (bkz. Norton ve Kastberg, 2012). Üstelik üst düzey bilişsel görevlerin öğrencilerin başarıları üzerinde olumlu etkilerinin olduğu da ifade edilmektedir (bkz. Winne, 1979; Redfield ve Rousseau, 1991). Ayrıca bu noktada, günlük hayat ilişkilerini de içeren matematiksel deneyimlerin, sınıf ortamlarına ancak üst düzey bilişsel görevler aracılığıyla taşınabileceği de unutulmamalıdır. Öğrenciler ancak bu şekilde matematik yapmanın anlamını ve hazzını daha kolay içselleştirebilirler (Schoenfeld, 1992). Benzer şekilde Henningsen ve Stein (1997) da görevlerin içeriğinin, öğrencilerin düşüncelerini etkileyebileceğini ve yapılandırabileceğini ve çalıştıkları konu veya kavrama ilişkin görüşlerini sınırlandırabileceğini ya da genişletebileceğini belirtmiştir. Dolayısıyla bu görevlerin seçimi, içeriği, planlaması ve uygulanması, öğrencilerin matematiği etkili biçimde öğrenebilmeleri ve daha önceden belirlenen eğitim hedeflerine ulaşabilmesi için (Hiebert vd., 1997) oldukça önem arz etmektedir. Zira görevler öğrencilere öğrenilen matematiksel konu veya kavramları düşünerek ve sorgulayarak öğrenmelerine yardımcı olacak içerikler sağlarlar. Üstelik farklı matematiksel görevler, öğrencilerde farklı düşünme düzeylerinin oluşmasına da yardımcı olurlar (Doyle 1983; Hiebert ve Wearne, 1993; Marx ve Walsh, 1988). Ayrıca görevlerin, öğrencilerin derse katılımını arttırma, önceki öğrenmeleri sorgulama, yorumlama, tartışma ortamı oluşturma, yaratıcı düşünmeyi destekleme, öğrenci yetenek ve becerilerini tanıma, hazırbulunuşluk düzeylerini gözden geçirme ve ilgi çekme vb. hususlarda daha önceden belirlenmiş eğitimsel hedeflere ulaşılıp ulaşılmadığının değerlendirilmesi noktasında da kullanışlı öğretimsel araçlar olduğu da belirtilmektedir (bkz. Van de Walle vd., 2019).

Matematiksel görevlerin matematik öğretimi üzerindeki bu önemi ve etkisi ise öğretmenlerin etkili ve nitelikli matematiksel görevleri oluşturma, seçme ve sınıf ortamlarında bunları uygulama noktasında ne kadar önemli bir role sahip olduklarını ortaya koymaktadır. Ancak ilgili literatür incelendiğinde, matematiksel görevlerle ilgili araştırmaların genellikle öğrenciler veya öğretmen adaylarıyla yürütüldüğü belirlenmiştir (bkz. Cumhur, Çavdar ve Polat, 2018; Türnüklü, Aydoğdu ve Ergin, 2017; Norton ve Kastberg, 2012; Tyminski, Land, Drake, Zambak, ve Simpson, 2014). Bu kapsamda bu çalışmanın ilgili literatürdeki bu önemli boşluğu doldurmaya namzet olduğu düşünülmektedir. Ayrıca bu çalışmanın, matematiksel görev türlerinin oluşturulmasında öğretmenler tarafından hangi konuların tercih edilmesini belirlemesi 
bakımından da ilgili literatüre önemli bir katkı sağlayabileceği düşünülmektedir. Bu bağlamda şimdiki çalışmada, aşağıdaki sorulara cevap aranmıştır:

1) Matematik öğretmenlerinin farklı matematiksel görev türü oluşturma durumları nasıldır?

2) Öğretmenlerin matematiksel görevleri oluştururken tercih ettikleri matematiksel konular

\section{YÖNTEM}

Araştırmada, nitel araştırma desenlerinden tekli durum çalışması yöntemi kullanılmıştır. Durum çalışması, sınırlı sayıdaki sistem, olgu, kişi, olay vb.nin derinlemesine araştırılması ve betimlenmesi olarak ifade edilmektedir (bkz. Creswell, 2013; Merriam, 2013). Bu bağlamda şimdiki çalışmanın durumu, matematik öğretmenleri iken analiz birimleri ise matematiksel görev türleri ve matematiksel konulardır.

\section{Katılımcılar}

Çalışma, 2019-2020 eğitim-öğretim yılı bahar yarıyılında Doğu Anadolu'daki bir ilin merkez ve ilçelerinde bulunan resmi ortaokullarda görev yapan ve kolay ulaşılabilir örnekleme yöntemi ile belirlenen 18 matematik öğretmeniyle gerçekleştirilmiştir. Bu öğretmenlerin, kıdemleri 1-15 arasında değişirken 10'u kadın, 8'i ise erkektir. Öğretmenlerin kıdemlerine bakıldığında, öğretmenlerin hepsinin 2000'li yıllarla birlikte Türkiye'de öğrenci merkezli bir anlayışla güncellenen/güncellenmekte olan matematik öğretim programlarından (Eğitim Fakültesi matematik öğretmenliği programları ve MEB matematik öğretim programları) mezun oldukları veya bu programların uygulayıcısı oldukları görülmektedir. Bu durum ise katılımcı grubun, şimdiki araştırmanın inceleme konusu olan matematiksel görevlere yönelik bir aşinalıklarının olduğu şeklinde değerlendirilmektedir.

\section{Veri Toplama Aracı ve İşlem}

Araştırma verileri, matematik eğitimi alanında doktora derecesine sahip iki uzmanın görüşlerinden de yararlanılarak hazırlanan açı-uçlu bir görüş formu aracıllğıyla toplanmıştır. Görüşme formu, öğretmenlerin 3 matematiksel görev türünün her birine yönelik görev oluşturma durumlarını vb. belirlemeye yönelik 4 sorudan oluşmuştur. Ancak şimdiki çalışmada görüşme formundaki sorulardan sadece aşağıda verilen sorunun cevabına odaklanılmış ve buradan elde edilen sonuçlar raporlaştırılmıştır:

Tür 1 (model), Tür 2 (bağlamsal) ve Tür 3 (açık-uçlu) matematiksel görev türlerinin her biri için iki matematiksel görev oluşturunuz? (Matematiksel görev türlerine yönelik açıklamalar görüş formunda belirtilmiştir).

Veri toplama sürecinde, katılımcılara çalışmayla ilgili detaylı bilgi verilmiş, isimlerinin araştırma amacı dışında kesinlikle kullanılmayacağı ve başkalarıyla paylaşılmayacağı ifade 
edilmiştir. Ayrıca katılımcılara, bulguların sunumunda gerçek isimleri yerine Ö1, Ö2, Ö3 vb. kodların kullanılacağı da belirtilmiştir.

\section{Verilerin Analizi}

Verilerin analizi, anlamsal içerik analizi kullanılarak yapılmıştır. Anlamsal içerik analizi, analize tabi tutulan verinin özündeki asıl konu alanlarını ve bu alanların içerdiği özel alt alanlarını belirlemeye yönelik bir kategori oluşturma işlemidir (Tavşancıl ve Aslan, 2001). Bu bağlamda şimdiki çalışmada, açık-uçlu görüş formundaki bir soruya (farklı matematiksel görevler oluşturma) verilen öğretmen cevapları (derinlemesine bir analiz yapabilmek için) raporlanmıştır. Matematiksel görev türleri (modele dayalı görevler, bağlama dayalı görevler ve açık uçlu görevler), verilerin özündeki asıl konu alanını temsil etmektedir ve her bir matematiksel görev türü, bunlara ilişkin özellikler/kodlar ve örnek görevler Ek 1'deki Tablo 4'te verilmiştir. Ayrıca burada, katılımcıların oluşturdukları görevlerin herhangi bir görev türü kapsamında değerlendirilebilmesi için o görev türüne ilişkin temel kodları ve toplam kodların/özelliklerin de en az \%70'ini sağlaması şartı da aranmıştır (bkz. Miles ve Huberman, 1994).

\section{Çalışmanın Güvenirliği}

Bu çalışmanın verileri, Sullivan vd. (2012)'nin önerdiği farklı matematiksel görev türleri (modele dayalı, bağlamsal ve açık uçlu görevler) ve bu görev türlerinin kodlarına/özelliklerine göre incelenmiştir (bkz. Tablo 4). Bu şekilde, burada verilerin "teorik üçgenlemesi" (Cohen, Manion ve Morrison, 2000; s.113) yapılmıştır. Diğer taraftan, verilerin güvenirliğinin sağlanmasında, üye kontrolünden de (bkz. Creswell, 1998) yararlanılmıştır. Bu bağlamda matematik öğretmenlerinin görüş formunda oluşturdukları görevler, araştırmacılar tarafından ilk önce bağımsız biçimde birkaç defa okunmuş ve incelenmiştir. Daha sonra, yukarıda belirtilen kategori ve kodlara göre öğretmenlerin oluşturdukları görevler, araştırmacılar tarafından birlikte ele alınmıştır. Bu adımda, öğretmenlerin oluşturdukları görevler ve buradaki ifadeleri üzerinde herhangi bir değişiklik yapılmamış, bu görevler ve ifadeler öğretmenlerin onayına tekrar sunulmuştur. Ayrıca, araştırma verilerinin güvenirliğinin sağlanması için akran incelemesinden de yararlanılmıştır (bkz. Lincoln ve Guba, 1985). Bu kapsamda, matematik eğitimi alanında doktora sahibi iki uzmana ham verilerin \%60'1 verilmiş (bkz. Macnealy, 1999) ve onlardan araştırma verilerini Tablo $4^{\prime}$ te verilen matematiksel görev ve kodlarına/özelliklerine göre incelemeleri istenmiştir. Verilerin analizi sonucunda, araştırmacılar ile kodlayıcı I ve kodlayıcı II arasındaki uyum katsayıları sırasıyla 0,81 ve 0,85 olarak hesaplanmıştır. Bu uyum katsayıları, verilerin analizinin güvenirliğinin yüksek düzeyde olduğunu göstermektedir (bkz. Miles ve Huberman, 1994). Bu süreçten sonra araştırmacılar, bu uzmanlarla ayrı ayrı bir araya gelmiş ve farklı düşünülen noktalar için ortak bir uzlaşı noktası aramıştır. Örneğin, kodlayıcı I, araştırmacılar gibi- görev türleri içerisinde yer alan "Bir açısı $40^{\circ}$ olan bir üçgenin diğer açıları kaç 
derece olabilir?" sorusunu "açık uçlu görev" olarak sınıflandırmıştır. Fakat kodlayıcı II, bu görevi "modele dayalı görev" kapsamında değerlendirmiştir. Sonuç olarak araştırmacılar, yukarıda verilen bu görevi açık uçlu görev türüne yerleştirmiştir. Diğer taraftan, bulgular kısmında katılımcıların kendi ifadelerine de yer verilmiştir. Böylece, bulguların raporlanması ve aktarımında derinlemesine bir betimleme ve zenginliğin olması da amaçlanmıştır (bkz. Creswell, 2012).

\section{BULGULAR}

Öğretmenler tarafından oluşturulan matematiksel görevler, her bir görev türü için ayrı ayrı incelenmiştir. Bu bağlamda, oluşturulan görevlere karşılık gelen kodlar ve öğretmenlerin bu görevleri yazarken tercih ettikleri matematiksel konular tablolar halinde sunulmuştur.

\section{Modele Bağlı Görevler}

Bu görev türüne yönelik bulgular, Tablo 1'de özetlenmiştir.

Tablo 1.

Modele Bağlı Görevler, Kodlar ve Görevlerin Konu Dă̆̆lımı

\begin{tabular}{|c|c|c|c|c|}
\hline $\begin{array}{l}\text { Görev } \\
\text { Türü }\end{array}$ & Katılımcı & $\begin{array}{l}\text { Oluşturulan } \\
\text { Görev Sayıs1 }\end{array}$ & Konu & Karşılık Gelen Kodlar \\
\hline \multirow{20}{*}{ 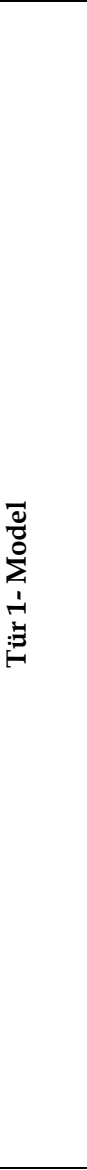 } & \multirow[b]{2}{*}{ Ö1 } & 1 & Cebirsel İfadeler & $1.3,1.4,1.6,1.7,1.15,1.14,1.18$ \\
\hline & & 2 & Üslü Sayılar & $1.2,1.4,1.6,1.10,1.11,1.15,1.16$ \\
\hline & \multirow{2}{*}{ Ö2 } & 1 & $\begin{array}{l}\text { Doğal Sayılarda } \\
\text { Çarpma }\end{array}$ & - \\
\hline & & 2 & $\begin{array}{l}\text { Doğal Sayılarda } \\
\text { Bölme }\end{array}$ & - \\
\hline & \multirow{2}{*}{ Ö3 } & 1 & Kesirler & $\begin{array}{l}\text { * Görev oluşturulmamış ama kullanılacak } \\
\text { model belirtilmiştir. }\end{array}$ \\
\hline & & 2 & Ondalık Sayılar & $\begin{array}{l}\text { Görev oluşturulmamış ama kullanılacak } \\
\text { model belirtilmiştir. }\end{array}$ \\
\hline & \multirow{2}{*}{ Ö4 } & 1 & Cebirsel İfadeler & $1.3,1.4,1.6,1.7,1.15,1.14,1.18$ \\
\hline & & - & - & - \\
\hline & \multirow{2}{*}{ Ö5 } & 1 & Kümeler & - \\
\hline & & 2 & Oran & - \\
\hline & \multirow{2}{*}{ Ö6 } & 1 & Tamsayılar & - \\
\hline & & - & - & - \\
\hline & \multirow{2}{*}{ Ö7 } & 1 & Kümeler & - \\
\hline & & 2 & Mutlak Değer & - \\
\hline & \multirow{2}{*}{ Ö8 } & 1 & Eşitlik ve Denge & $\begin{array}{l}\text { 1.1, 1.2, 1.3, 1.4, 1.6, 1.9, 1.12, 1.13, 1.14, 1.15, 1.17, } \\
1.18\end{array}$ \\
\hline & & - & - & - \\
\hline & \multirow{2}{*}{ Ö9 } & 1 & Kesirler & $\begin{array}{l}\text { 1.1, 1.2, } 1.3,1.4,1.6,1.7,1.8,1.9,1.10,1.12,1.13,1.14 \text {, } \\
1.15,1.17,1.18\end{array}$ \\
\hline & & 2 & Kesirler & $\begin{array}{l}1.1,1.2,1.3,1.4,1.6,1.7,1.8,1.9,1.10,1.12,1.13,1.14 \text {, } \\
1.15,1.17,1.18\end{array}$ \\
\hline & \multirow{2}{*}{ Ö10 } & 1 & Cebirsel İfadeler & $\begin{array}{l}\text { 1.1, 1.2, 1.3, 1.4, 1.5, 1.6, 1.8, 1.9, 1.11, 1.13, 1.14, 1.15, } \\
1.16,1.17,1.18\end{array}$ \\
\hline & & 2 & $\begin{array}{l}\text { Üçgende Çevre } \\
\text { Hesaplama }\end{array}$ & $1.3,1.4,1.5,1.6,1.8,1.9,1.14,1.15,1.16,1.17,1.18$ \\
\hline
\end{tabular}


Tablo 1.

Devam

\begin{tabular}{|c|c|c|c|}
\hline \multirow{2}{*}{ Ö11 } & 1 & Doğal Sayılar & - \\
\hline & 2 & Sayı Problemleri & - \\
\hline \multirow[b]{2}{*}{ Ö12 } & 1 & Sayı Problemleri & - \\
\hline & - & - & - \\
\hline \multirow[t]{2}{*}{ Ö13 } & 1 & Kesirler & $\begin{array}{l}\text { Görev oluşturulmamış ama kullanılacak } \\
\text { model belirtilmiştir. }\end{array}$ \\
\hline & - & - & - \\
\hline \multirow[b]{2}{*}{ Ö14 } & 1 & Tamsayılar & $1.3,1.4,1.6,1.10,1.14,1.15,1.17,1.18$ \\
\hline & 2 & Sayılar & $\begin{array}{l}\text { 1.1, 1.2, 1.3, 1.4, 1.5, 1.6, 1.8, 1.9, 1.10, 1,11, 1.12, 1.13, } \\
\text { 1.14, } 1.15,1.16,1.17,1.18\end{array}$ \\
\hline \multirow{2}{*}{ Ö15 } & - & - & - \\
\hline & - & - & - \\
\hline \multirow{2}{*}{ Ö16 } & - & - & - \\
\hline & - & - & - \\
\hline \multirow{2}{*}{ Ö17 } & 1 & Tamsayılar & $\begin{array}{l}\text { Görev oluşturulmamış ama kullanılacak model } \\
\text { belirtilmiştir. }\end{array}$ \\
\hline & 2 & Özdeşlikler & $\begin{array}{l}\text { Görev oluşturulmamış ama kullanılacak model } \\
\text { belirtilmiştir. }\end{array}$ \\
\hline \multirow[b]{2}{*}{ Ö18 } & 1 & Katı Cisimler & $1.2,1.3,1.4,1.6,1.9,1.14,1.15,1.18$ \\
\hline & 2 & Üslü Sayılar & $\begin{array}{l}\text { 1.1, 1.2, 1.3, 1.4, 1.5, 1.6, 1.7, 1.8, 1.9, 1.10, 1.11, 1.13, } \\
1.14,1.15,1.16,1.17\end{array}$ \\
\hline
\end{tabular}

* Katılımcı tarafından bir görevin oluşturulmadığı fakat hangi konuda hangi model veya temsilin kullanılacağının belirtildiği durum.

Tablo 1 incelendiğinde, 18 öğretmenden 13'ünün (\%72) bu görev türüne yönelik görevler oluşturduğu görülmektedir. Bu bağlamda, katılımcıların 4'nün bir, 9'unun ise iki görev olmak üzere toplam 22 görev oluşturdukları belirlenmiştir. Bu görevlerin ise 12'si (\%55) genel anlamda modele dayalı görev türü (Tür 1) kapsamında değerlendirilmiştir. Bu 12'i görevin ise 6'sının (\%50) bu görev türüne ilişkin temel kodları ve bütün kodların en az \%70'ni sağladığı belirlenmiştir (ör. Ö9, Ö18). Geriye kalan 6 görevin ise bu göreve yönelik kodların en az \%70'ni sağlayamadığı sadece bazı temel kodları (ör. 1.3, 1.4) sağladığı tespit edilmiştir (ör. Ö1, Ö4).

Model görev türüne ait temel kodları sağlayan ve bu görev türünün özelliklerinin/kodlarının en az \%70'ini sağlayan bir görev alıntısı aşağıda verilmiştir.

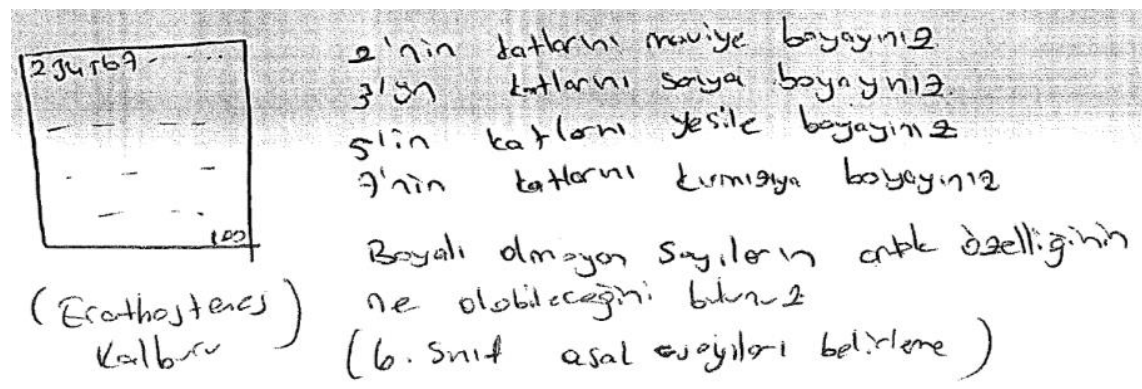

Şekil 1. Ö14'ün asal sayıların öğrenimine yönelik oluşturduğu görev

Şekil 1'den görüleceği üzere, Ö14'un asal sayıların öğrenimine yönelik oluşturduğu görev, model görev türünün 1. 1, 1.2, 1.3, 1.4, 1.5, 1.6, 1.8, 1.9, 1.10, 1.11, 1.12, 1.13, 1.14, 1.15, 1.16, 1.17, 1.18 (\%89) kodlarıyla eşleştirilebilmektedir.

Model görev türüne ait temel kodları sağlayan fakat bu görev türünün özelliklerinin/kodlarının en az \%70'ini sağlamayan bir görev alıntısı aşağıda verilmiştir. 


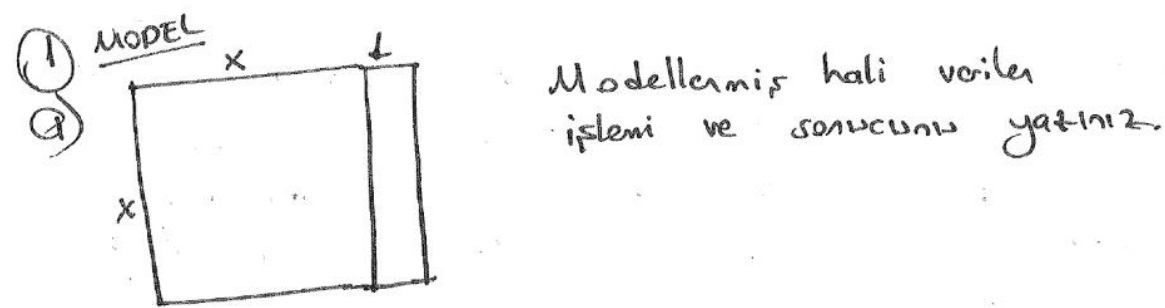

Şekil 2. Ö4'ün Cebirsel Iffadelerin Öğrenimine Yönelik Oluşturduğu Görev

Şekil 2'de görüleceği üzere, Ö4 kodlu katılımcının cebirsel ifadelerin öğrenimine yönelik oluşturduğu görev, model görev türünün 1.3, 1.4, 1.6, 1.7, 1.14, 1.15, 1.18 (\%39) kodlarıyla eşleştirilmiştir. Ancak Ö4'un oluşturduğu bu görev, model görev türüne ilişkin kodların en az \%70'ni sağlamadığı için model görev türü kapsamında değerlendirilmemiştir.

Model görev türüne ait temel kodları sağlamadığından değerlendirmeye alınmayan göreve yönelik bir örnek alıntı ise aşağıdadır.

2. 50 .

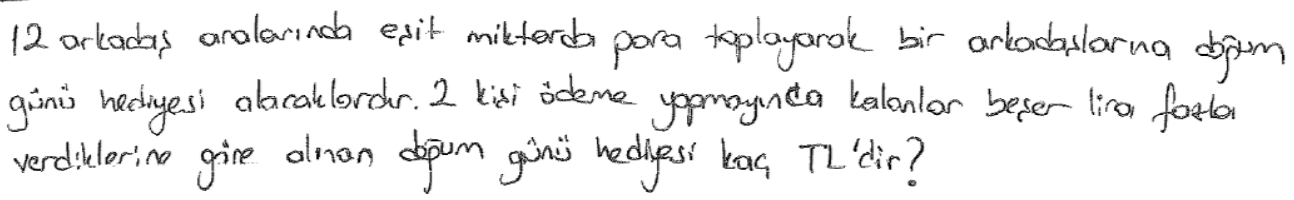

Şekil 3. Ö11'in Sayı Problemlerinin Öğrenimine Yönelik Oluşturduğu Görev

Şekil 3'te görüleceği üzere, Ö11 kodlu katılımcının sayı problemlerinin öğrenimine yönelik oluşturduğu görev, model görev türünün temel kodlarıyla eşleştirilememiştir. Aynı zamanda, bu görevin model görev türüne ilişkin kodların en az \%70'ini sağlamadığı da görülmektedir. Diğer taraftan, bazı katılımcıların (ör, Ö3, Ö17) model görev türüne yönelik herhangi bir görev oluşturmadığı, görev oluşturmak yerine hangi konuda hangi model/temsil kullanılacağına dair bazı açıklamalarda bulundukları belirlenmiştir. Bu duruma yönelik bir örnek alıntı ise aşağıda verilmiştir.

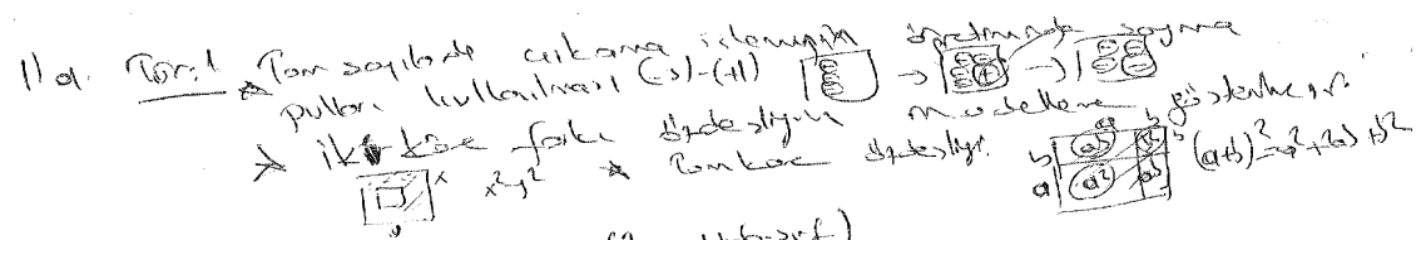

*Şekil 4. Tamsayılar ve Özdeşlik Konularının Içerdikleri Modellere Dair Açıklamalar

Şekil 4'te görüleceği gibi, Ö17 kodlu öğretmen herhangi bir görev oluşturmamış fakat tamsayılarla çıkarma işleminde sayı pullarının kullanılmasını ve bazı özdeşliklerin modelleme yoluyla temsilinin yapılmasını örneklemeye çalışmıştır.

Diğer taraftan, Tablo 1'den katılımcıların görevleri oluştururken tercih ettikleri konular incelendiğinde ise bu görev türünün temel kodlarını ve tüm kodlarının en az \%70' ini sağlayan 
görevlerin (6 görev), kesirler (2), eşitlik ve denge (1), cebirsel ifadeler (1), sayılar (1), üslü sayılar (1) konularında yoğunlaştığı görülmektedir. Model görev türünün temel kodlarını sağlayan fakat en az \%70'ini karşılamayan görevlerin (6 görev) ise cebirsel ifadeler (2), üçgende çevre hesaplama (1), katı cisimler (1), tamsayılar (1), üslü sayılar (1) konuları baz alınarak oluşturulmaya çalışıldığı belirlenmiştir. Diğer taraftan, model görev türü kapsamında değerlendirilmeyen görevlerin (10 görev) ise doğal sayılarda çarpma (1), doğal sayılarda bölme (1), kümeler (2), oran (1), tamsayılar (1), mutlak değer (1), doğal sayılar (1), sayı problemleri (2) konularına yönelik olduğu da belirlenmiştir (bkz. Tablo 1).

\section{Bağlama Dayalı Görevler}

Tablo 2 incelendiğinde, 18 öğretmenden 16'sının (\%89) bu görev türüne yönelik görevler oluşturduğu belirlenmiştir. Öğretmenlerin 7'sinin bir, 9'unun ikişer olmak üzere toplam 25 görev oluşturulduğu belirlenmiştir. Bu görevlerin ise 15'i (\%60) bağlama dayalı görev türü (Tür 2) kapsamında değerlendirilmiştir. Bu görevler incelendiğinde 6'nın (\%40) bu görev türüne ilişkin temel kodları ve bütün kodların en az \%70'ni sağladığı belirlenmiştir (ör. Ö13, Ö17). Bağlama dayalı görev türünde değerlendirilmeyen görevlerin ise bu göreve ilişkin kodların sadece bazı kodlarını (ör. 2.1, 2.6) sağladığı fakat kodların \%70'ni sağlamadığı tespit edilmiştir. Bu görev türüne yönelik bulgular, Tablo 2' de özetlenmiştir.

\section{Tablo 2.}

Bağlama Dayahı Görevler, Kodlar ve Görevlerin Konu Dağılımı

\begin{tabular}{|c|c|c|c|c|}
\hline $\begin{array}{l}\text { Görev } \\
\text { Türü }\end{array}$ & Katılımcı & $\begin{array}{l}\text { Oluşturulan } \\
\text { Görev Sayısı }\end{array}$ & Konu & Karşılık Gelen Kodlar \\
\hline \multirow{14}{*}{ 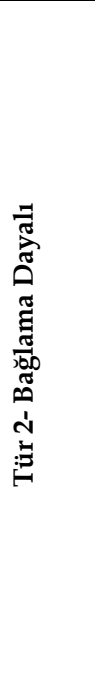 } & \multirow[t]{2}{*}{ Ö-1 } & 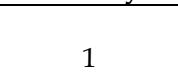 & Sayı Problemleri & $\begin{array}{l}\text { 2.1, 2.3, 2.4, 2.6, 2.7, 2.8, 2.9, 2.10, 2.11, 2.16, 2.18, } \\
2.20,2.21,2.22\end{array}$ \\
\hline & & 2 & Alan Hesaplama & - \\
\hline & \multirow[b]{2}{*}{ Ö-2 } & 1 & Sayı problemleri & - \\
\hline & & 2 & Pisagor Bağıntısı & - \\
\hline & \multirow{2}{*}{ Ö-3 } & 1 & Ondalık Sayılar & - \\
\hline & & 2 & Ondalık Sayılar & - \\
\hline & \multirow[t]{2}{*}{ Ö-4 } & 1 & $\begin{array}{c}\text { Alan } \\
\text { Hesaplama }\end{array}$ & $2.1,2.2,2.4,2.8,2.9,2.10,2.11,2.16,2,21,2.22$ \\
\hline & & - & - & - \\
\hline & \multirow{2}{*}{ Ö-5 } & 1 & Kesir Problemleri & - \\
\hline & & 2 & Tamsayılar & - \\
\hline & \multirow[t]{2}{*}{ Ö-6 } & 1 & Sayı Problemleri & $\begin{array}{l}\text { 2.1, 2.2, 2.3, 2.5, 2.6, 2.8, 2.9, 2.10, 1.11, 2.14, 2.15, } \\
2.16,2.18,2.19,2.20,2.21,2.22,2.23\end{array}$ \\
\hline & & - & - & - \\
\hline & \multirow{2}{*}{ Ö-7 } & 1 & Kesirler & $2.1,2.3,2.6,2.9,2.11,2.16,2.21$ \\
\hline & & - & - & - \\
\hline
\end{tabular}


Tablo 2.

Devam

\begin{tabular}{|c|c|c|c|}
\hline \multirow{2}{*}{ Ö-8 } & 1 & Kesirler & $2.6,2.8,2.9,2.11,2.16,2.21,2.22$ \\
\hline & - & - & - \\
\hline \multirow{2}{*}{ Ö-9 } & 1 & Sayı Problemleri & $\begin{array}{l}\text { 2.1, 2.3, 2.4, 2.6, 2.8, 2.9, 2.10, 2.11, 2,12, 2.16, 2.19, } \\
2.21,2.23\end{array}$ \\
\hline & 2 & Sayı Problemleri & $\begin{array}{l}\text { 2.1, 2.2, 2.3, 2.4, 2.6, 2.8, 2.9, 2.10, 2.11, 2.16, 2.18, } \\
2.21,2.22\end{array}$ \\
\hline \multirow[b]{2}{*}{ Ö-10 } & 1 & Ölçme & $\begin{array}{l}2.1,2.2,2.3,2.4,2.5,2.6,2.7,2.8,2.10,2.11,2.12 \\
2.13,2.16,2.17,2.18,2.19,2.20,2.21,2.22,2.23\end{array}$ \\
\hline & 2 & $\begin{array}{c}\text { Üslü } \\
\text { Sayılar } \\
\end{array}$ & $\begin{array}{l}2.1,2.2,2.3,2.6,2.7,2.8,2.9,2.10,2.11,2.13,2.14, \\
2.15,2.16,2.17,2.18,2.19,2.20,2.22,2.23\end{array}$ \\
\hline \multirow{2}{*}{ Ö-11 } & 1 & Say1 Problemleri & - \\
\hline & 2 & Kesirler & - \\
\hline \multirow{2}{*}{ Ö-12 } & 1 & Sayı Problemleri & - \\
\hline & - & - & - \\
\hline \multirow{2}{*}{ Ö-13 } & 1 & $\begin{array}{c}\text { Zaman Hesaplama } \\
\text { Problemleri }\end{array}$ & $\begin{array}{l}2.1,2.2,2.4,2.5,2.6,2.7,2.8,2.9,2.10,2.11,2.13,2.14, \\
2.15,2.16,2.17,2.18,2.19,2.20,2.21,2.22,2.23\end{array}$ \\
\hline & - & - & - \\
\hline \multirow{2}{*}{ Ö-14 } & 1 & Kesirler & $2.1,2.3,2.5,2.6,2.8,2.9,2.10,2.11,2.16,2.21$ \\
\hline & 2 & $\begin{array}{c}\text { Kar- Zarar } \\
\text { Problemleri }\end{array}$ & $2.1,2.3,2.4,2.5,2.6,2.8,2.9,2.10,2.11,2.16,2.21$ \\
\hline \multirow{2}{*}{ Ö-15 } & - & - & - \\
\hline & - & - & - \\
\hline \multirow{2}{*}{ Ö-16 } & - & - & - \\
\hline & - & - & 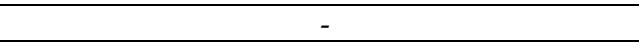 \\
\hline \multirow{2}{*}{ Ö-17 } & 1 & Oran & $\begin{array}{l}\text { 2.1, 2.3, 2.4, 2.5, 2.6, 2.7, 2.8, 2.9, 2.10, 2.10, 2.11, 2.13, } \\
2.16,2.17,2.18,2.19,2.20,2.21,2.22,2.23\end{array}$ \\
\hline & 2 & Ölçme & $\begin{array}{l}2.1,2.2,2.3,2.4,2.5,2.6,2.7,2.8,2.9,2.10,2.11,2.13 \\
2.14,2.15,2.16,2.17,2.18,2.19,2.20,2.21,2.22,2.23\end{array}$ \\
\hline \multirow[t]{2}{*}{ Ö-18 } & 1 & Litre Problemleri & $\begin{array}{l}\text { 2.1, 2.2, 2.3, 2.6, 2.8, 2.9, 2.10, 2.11, 2.16, 2.17, 2.18, } \\
2.21,2.22\end{array}$ \\
\hline & - & - & \\
\hline
\end{tabular}

Bağlama dayalı görev türüne ait temel kodları sağlayan ve bu görev türünün özelliklerinin/ kodlarının en az \% 70'ini sağlayan bir görev alıntısı aşağıdadır:

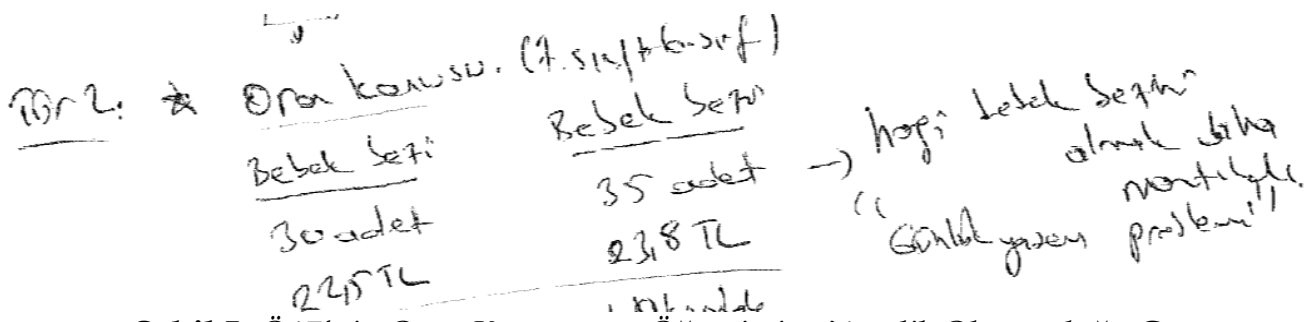

Şekil 5. Ö17'nin Oran Konusunun Öğrenimine Yönelik Oluşturduğu Görev

Şekil 5' te görüleceği gibi, Ö17'nin oran konusunun öğrenimine yönelik oluşturduğu görev, bağlama dayalı görev türünün 2.1, 2.3, 2.4, 2.5, 2.6, 2.7, 2.8, 2.9, 2.10, 2.11, 2.13, 2.16, 2.17, 2.18, 2.19, 2.20, 2.22, 2.23 (\%78) kodlarıyla eşleştirilebilmektedir. 
Bağlama dayalı görev türüne ait temel kodları sağlayan fakat bu görev türünün özelliklerinin/kodlarının en az \%70'ini sağlamayan bir görev alıntısı ise aşağıdadır:

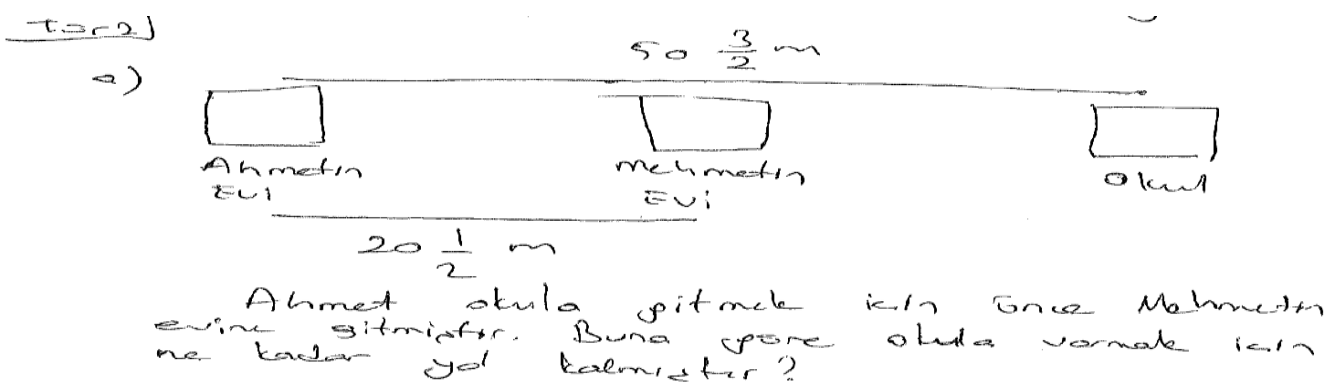

Şekil 6. Ö7'nin Oran Konusunun Öğrenimine Yönelik Oluşturduğu Görev

Şekil 6'da görüleceği üzere, Ö7'nin kesirler konusunun öğrenimine yönelik oluşturduğu görev, bağlama dayalı görev türünün, 2.1, 2.3, 2.6, 2.9, 2.11, 2.16, 2.21 (\%30) kodlariyla eşleştirilebilmektedir. Ancak Ö7'nin oluşturduğu bu görev, bağlama dayalı görev türüne ilişkin kodların en az \%70'ni sağlamadığı için bağlama dayalı görev türü kapsamında ele alınmamıştır. Ayrıca, Şekil 6'da verilen görev, bağlama dayalı görev türünün bazı kodlarıyla eşleşmesine rağmen, bu görevin temel düzeyde günlük hayatla ilişki kurduğu ve buradaki asıl amacın kesirlerle işlem becerisini geliştirmek olduğu söylenebilir. Bu tarz sorular, bağlama dayalı görev türünde değerlendirilmemelerine rağmen, günlük hayatla basit düzeyde de olsa ilişki kurduklarından, bu görevlerin hangi kodlarla eşleştikleri Tablo 2' de verilmiştir. Bağlama dayalı görev türü ve sözel problem kategorisine girmeyen sorular değerlendirilmediği için eşleştikleri kodlar Tablo 2'de verilmemiştir (ör, Ö3, Ö5). Ek olarak burada, bağlama dayalı görev türü kapsamında değerlendirilemeyen bazı sorular, sözel problemler kapsamında değerlendirilebilir. Bu tür sorular ise dört işlem becerisini geliştirme, kavramsal anlamayı destekleme, basit düzeyde günlük hayatla ilişki kurma ve tahmin etme vb. özellikleri içermektedir. Bağlama dayalı görev türüne ait temel kodları sağlamadığından değerlendirmeye alınmayan göreve yönelik bir örnek alıntı ise aşağıda verilmiştir.

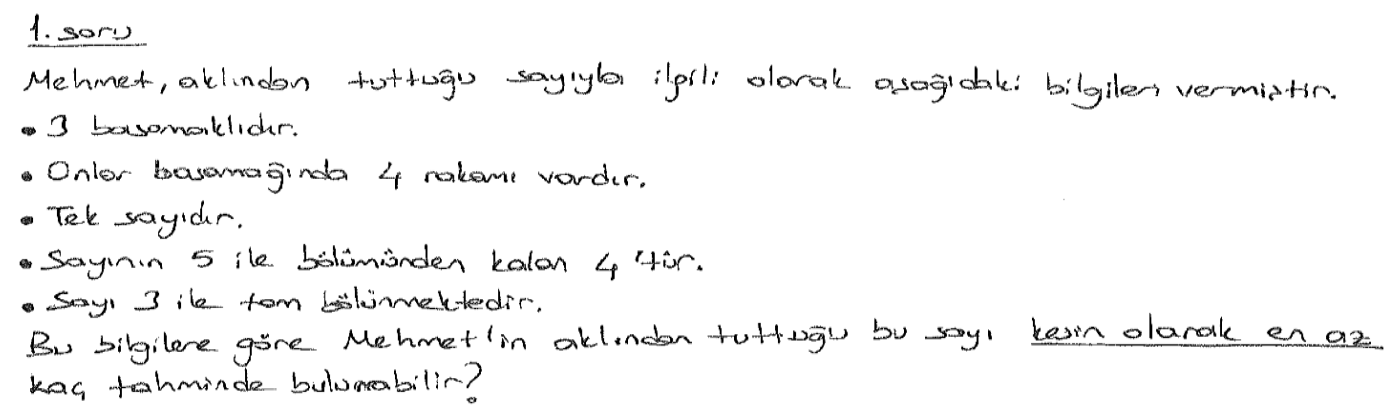

Şekil 7. Ö11'in Sayılar Konusunun Öğrenimine Yönelik Oluşturduğu Görev

Şekil 7'de görüleceği üzere, Ö11 kodlu katılımcının sayılar konusunun öğrenimine yönelik oluşturduğu görev, bağlama dayalı görev türünün temel kodlarıyla eşleştirilememiştir. Oluşturulan görevin, bağlama dayalı görev türüne ilişkin kodların en az \%70 ni sağlamadığı da görülmektedir. 
Diğer taraftan, Tablo 2'deki katılımcıların görevleri oluştururken tercih ettikleri konular incelendiğinde ise, bu görev türünün kodlarının en az \%70' ini karşılayan görevlerin (6 görev), sayı problemleri (1), ölçme (2), zaman hesaplama problemleri (1), üslü sayılar (1) ve oran (1) konularında yoğunlaştığı görülmektedir. Bağlama dayalı görev türünün kodlarının en az \% 70'ini karşılamayan görevlerin (9 görev) ise sayı problemleri (3), alan (1), kar- zarar problemleri (1), litre problemleri (1), kesirler (3) konuları baz alınarak oluşturulmaya çalışıldığı belirlenmiştir. Bağlama dayalı görev türü kapsamında değerlendirilmeyen görevlerin (10 görev) ise alan hesaplama (1), sayı problemleri (3), Pisagor bağıntısı (1), ondalık sayılar (2), kesir problemleri (1), tamsayılar (1), kesirler (1) konularına yönelik olduğu da belirlenmiştir (bkz. Tablo 2).

\section{Açık Uçlu Görevlerin (Tür 3) Analizine Dair Bulgular}

Tablo 3 incelendiğinde, 18 öğretmenden 16'nın (\%89) bu görev türüne yönelik görevler oluşturduğu belirlenmiştir. Bu bağlamda katılımcıların 6'nın iki, 10'nun bir görev olmak üzere toplam 22 görev oluşturdukları görülmektedir. Bu görevlerin ise 13’ü (\%50) açık uçlu görev türü (Tür 3) kapsaminda değerlendirilmiştir (ör, Ö1, Ö4). Bu görevler incelendiğinde 8'nin (\%62) bu görev türüne ilişkin temel kodları ve toplam kodların en az \%70'ni sağladığı belirlenmiştir (ör, Ö10, Ö17). Kodların \%70'ni sağlamasına rağmen, çoklu cevap içermeyen görevler (5 görev) açık uçlu görev türüne dahil edilmemiştir (örneğin, Ö6, Ö7). Bu görev türüne yönelik bulgular, Tablo 3'te özetlenmiştir.

Tablo 3.

Açık Uçlu Görevler, Kodlar ve Görevlerin Konu Dağılımı

\begin{tabular}{|c|c|c|c|c|}
\hline $\begin{array}{l}\text { Görev } \\
\text { Türü }\end{array}$ & Katılımcı & $\begin{array}{l}\text { Oluşturulan } \\
\text { Görev Sayısı }\end{array}$ & Konu & Karşılık Gelen Kodlar \\
\hline \multirow{14}{*}{ 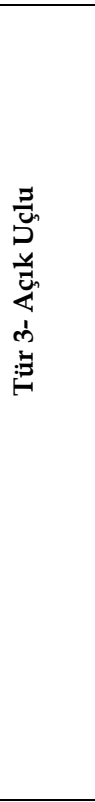 } & \multirow{2}{*}{ Ö-1 } & 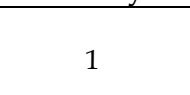 & Olasılık & $\begin{array}{l}\text { 3.1, 3.2, 3.3, 3.4, 3.5, 3.6, 3.7, 3.8, 3.9, 3.10, 3.11, 3.12, } \\
3.13,3.14,3.15,3.16\end{array}$ \\
\hline & & 2 & Sayılar & $\begin{array}{l}\text { 3.1, 3.2, 3.4, 3.5, 3.6, 3.7, 3.8, 3.9, 3.10, 3.11, 3.12, 3.13, } \\
\text { 3.14, 3.15, 3.16 }\end{array}$ \\
\hline & \multirow[t]{2}{*}{ Ö-2 } & 1 & Cebirsel İfadeler & - \\
\hline & & - & - & - \\
\hline & \multirow[t]{2}{*}{ Ö-3 } & 1 & Sayılar & $\begin{array}{l}\text { 3.1, 3.2, 3.4, 3.5, 3.6, 3.7, 3.9, 3.10, 3.11, 3.12, 3.14, } \\
3.15,3.16\end{array}$ \\
\hline & & 2 & Ondalık Sayılar & - \\
\hline & \multirow[t]{2}{*}{ Ö-4 } & 1 & $\begin{array}{c}\text { Sayı } \\
\text { Problemleri }\end{array}$ & $\begin{array}{l}\text { 3.2, 3.4, 3.5, 3.6, 3.7, 3.8, 3.10, 3.11, 3.12, 3.13, 3.14, } \\
3.15,3.16\end{array}$ \\
\hline & & - & - & - \\
\hline & \multirow{2}{*}{ Ö-5 } & 1 & Kümeler & - \\
\hline & & - & - & - \\
\hline & \multirow[t]{2}{*}{ Ö-6 } & 1 & $\begin{array}{c}\text { Kesir } \\
\text { Problemleri } \\
\end{array}$ & $\begin{array}{l}3.2,3.4,3.5,3.7,3.8,3.10,3.11,3.12,3.13,3.14,3.15 \text {, } \\
3.16\end{array}$ \\
\hline & & - & - & - \\
\hline & \multirow[t]{2}{*}{ Ö-7 } & 1 & $\begin{array}{c}\text { Sayı } \\
\text { Problemleri } \\
\end{array}$ & $\begin{array}{l}3.2,3.4,3.5,3.7,3.8,3.10,3.11,3.12,3.13,3.14,3.15 \text {, } \\
3.16\end{array}$ \\
\hline & & - & - & - \\
\hline
\end{tabular}


Tablo 3.

Devam

\begin{tabular}{|c|c|c|c|}
\hline \multirow[t]{2}{*}{ Ö-8 } & 1 & $\begin{array}{l}\text { Cebirsel } \\
\text { Iffadeler }\end{array}$ & $\begin{array}{l}\text { 3.2, 3.4, 3.5, 3.7, 3.8, 3.9, 3.10, 3.11, 3.12, 3.14, } \\
3.15,3.16\end{array}$ \\
\hline & - & - & - \\
\hline \multirow{2}{*}{ Ö-9 } & 1 & Sayılar & $3.2,3.4,3.5,3.7,3.9,3.10,3.11,3.12,3.13,3.16$ \\
\hline & 2 & Sayılar & $\begin{array}{l}\text { 3.1, 3.2, 3.4, 3.5, 3.7, 3.9, 3.10, 3.11, 3.12, 3.13, 3.14, } \\
3.16\end{array}$ \\
\hline \multirow{2}{*}{ Ö-10 } & 1 & Çarpanlara Ayırma & $\begin{array}{l}3.1,3.2,3.4,3.5,3.6,3.7,3.9,3.10,3.11,3.12,3.14 \\
3.16\end{array}$ \\
\hline & 2 & Sayılar & $\begin{array}{l}\text { 3.1, 3.2, 3.4, 3.5, 3.6, 3.7, 3.9, 3.10, 3.11, 3.12, 3.13, } \\
3.14,3.16\end{array}$ \\
\hline \multirow[b]{2}{*}{ Ö-11 } & 1 & Tamsayilar & - \\
\hline & 2 & Tamsayılar & $\begin{array}{l}\begin{array}{l}\text { 3.1, 3.2, 3.3, 3.4, 3.5, 3.6, 3.7, 3.11, 3.12, 3.13, 3.14, } \\
3.15,3.16\end{array} \\
\text {, }\end{array}$ \\
\hline \multirow[t]{2}{*}{ Ö-12 } & 1 & $\begin{array}{c}\text { Alan } \\
\text { Hesaplama } \\
\end{array}$ & - \\
\hline & - & - & - \\
\hline \multirow[t]{2}{*}{ Ö-13 } & 1 & $\begin{array}{l}\text { Üçgende } \\
\text { Uzunluk }\end{array}$ & \\
\hline & - & - & - \\
\hline \multirow{2}{*}{ Ö-14 } & 1 & Sayilar & \\
\hline & 2 & Ekok & \\
\hline \multirow[b]{2}{*}{ Ö-15 } & - & - & - \\
\hline & - & - & - \\
\hline \multirow{2}{*}{ Ö-16 } & - & - & - \\
\hline & - & - & - \\
\hline \multirow[t]{2}{*}{ Ö-17 } & 1 & Bölme Bölünebilme & $\begin{array}{l}3.1,3.2,3.3,3.4,3.5,3.6,3.7,3.8,3.9,3.10,3.11,3.12, \\
3.13,3.14,3.16\end{array}$ \\
\hline & - & - & - \\
\hline \multirow{2}{*}{ Ö-18 } & 1 & Veri Analizi & \\
\hline & - & - & \\
\hline
\end{tabular}

Açık uçlu görev türüne ait temel kodları ve bu görev türünün özelliklerinin/kodlarının en az \%70'ini sağlayan bir görev alıntısı aşağıda sunulmuştur:

Aaik-uals

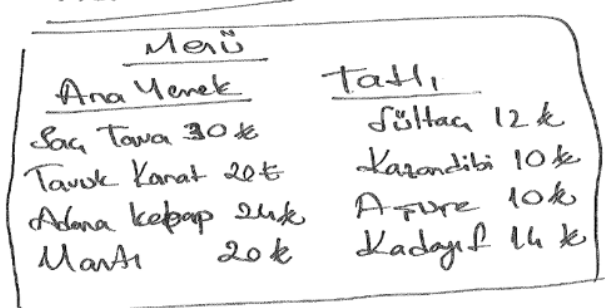

Bis Iokantada bir cessit ana yerrek

ve bir cuesit tath siporigi veren

bir misternin 20 t'st oldespuna

gore kaa farkh siparis vereblir?

Şekil 8. Ö4'ün Sayma Konusunun Öğretimine Yönelik' Olüş̧urdŭğu Görev

Şekil 8'de görüleceği üzere, Ö4'ün sayma konusunun öğretimine yönelik oluşturduğu görev, açık uçlu görev türünün 3.2, 3.4, 3.5, 3.6, 3.7, 3.8, 3.10, 3.11, 3.12, 3.13, 3.14, 3.15, 3.16 (\%81) kodlarıyla eşleştirilebilmektedir. Sorunun, bu görev türüne ilişkin kodların en az \% 70' ni sağladı̆̆1 ve birden fazla cevap içerdiği görülmektedir.

Katılımcılar tarafından oluşturulan görevler incelendiğinde, açık uçlu görev türüne ait temel kodları sağlamasına rağmen, kodları \%70 altında sağlayan bir görevin bulunmadığ1 tespit edilmiştir. Oluşturulan görevlerin kodlarla \%70 ve üzerinde eşleşebildiği fakat temel kodlarla 
eşleştirilemediklerinden dolayı açık uçlu görev türü olarak ele alınmadıkları dikkat çekmektedir (ör, Ö6, Ö9).

Açık uçlu görev türüne ait temel kodları sağlamayan fakat bu görev türünün özelliklerinin/kodlarının en az \%70'ini sağlayan bir görev alıntısı aşağıda verilmiştir.

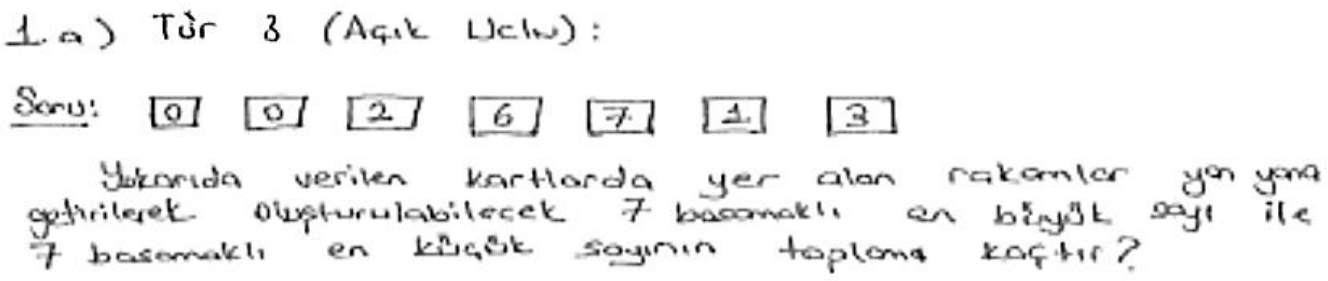

Şekil 9. Ö9'un Sayllar Konusunun Öğretimine Yönelik Oluşturduğu Görev

Şekil 9'da görüleceği gibi, Ö9'un sayılar konusunun öğretimine yönelik oluşturduğu görev, açık uçlu görev türünün 3.1, 3.2, 3.4, 3.5, 3.7, 3.9, 3.10, 3.11, 3.12, 3.13, 3.14, 3.16 (\%75) kodlarıyla eşleştirilebilmektedir. Sorunun, bu görev türüne ilişkin kodların en az \%70'ni sağladığ1 fakat açık uçlu görev türünün temel kodlarıyla eşleştirilemediği belirlenmiştir. Bu görevler, ilgili kodların en az \%70'ni “sağlamadıkları" için açık uçlu görev türünde ele alınmamalarına rağmen içerdikleri kodlar tabloda verilmiştir.

Açık uçlu görev türüne ait temel kodları sağlamadığından ve kodlarla en az \%70 düzeyinde eşleştirilemediğinden değerlendirmeye alınmayan görevlere yönelik bir örnek alıntı ise aşağıdadır:

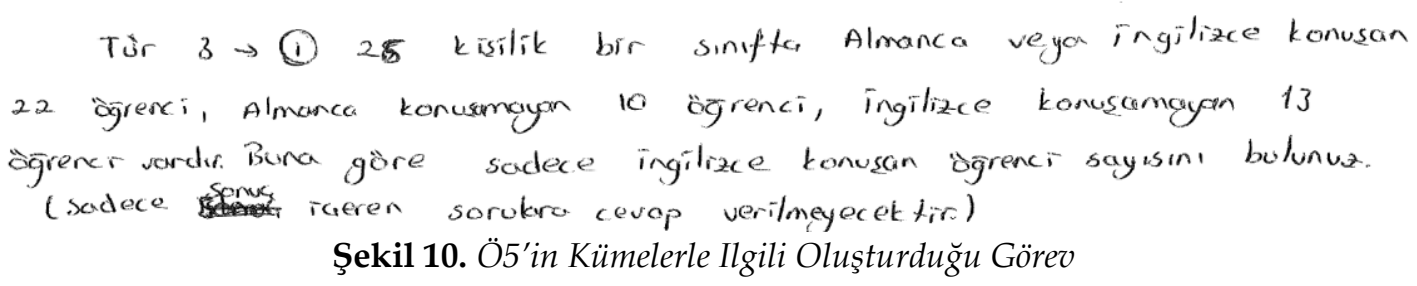

Şekil 10. Ö5'in Kümelerle Ilgili Oluşturduğu Görev

Şekil 10'da görüldüğü gibi, Ö5'in kümelerle ilgili oluşturduğu görev, açlk uçlu görev türünün temel kodlarıyla eşleştirilememiştir. Dolayısıyla katılımcılar tarafından oluşturulan bazı görevlerin, hiçbir şekilde açık uçlu görev türüne girmediği (ör, Ö2, Ö14) ve bu görevlerin kodlarla eşleştirilmesinin yapılamadığı görülmüştür.

Diğer taraftan, Tablo 3'te katılımcıların görevleri oluştururken tercih ettikleri konular incelendiğinde, bu görev türünün kodlarının en az \%70'ini karşılayan görevlerin (8 görev), sayı problemleri (1), olasılık (1), bölme ve bölünebilme (1), sayılar (3), çarpanlarına ayırma (1) ve tamsayılar (1) konularında yoğunlaştığı görülmektedir. Açık uçlu görev türünün kodlarının en az \%70'ini karşılayan fakat temel kodu (3.6) sağlamayan görevlerin (5 görev) ise sayı problemleri (1), kesir problemleri (1), cebirsel ifadeler (1) ve sayılar (2), konuları baz alınarak oluşturulmaya çalışıldığı belirlenmiştir. Açık uçlu görev türü kapsamında değerlendirilmeyen görevlerin (9 görev) ise alan hesaplama (1), üçgende uzunluk (1), ekok (1), veri analizi (1), sayılar (1), cebirsel 
ifadeler (1), ondalık sayılar (1), kümeler (1), tamsayılar (1) konularına yönelik olduğu da belirlenmiştir (bkz. Tablo 3).

\section{TARTIŞMA}

$\mathrm{Bu}$ çalışmada, ortaokul matematik öğretmenlerinin matematiksel görev oluşturma durumları ve bu görevleri oluştururken tercih ettikleri konular incelenmiştir. Bunun için Sullivan ve ark. (2012), tarafından önerilen 3 matematiksel görev türü (model-bağlamsal-açık uçlu) esas alınmış ve buna dayalı olarak tartışma kısmı iki alt başlık altında sunulmuştur: matematik öğretmenlerinin matematiksel görev oluşturma durumları ve bu görevleri oluştururken tercih ettikleri konular.

\section{Matematiksel Görev Oluşturma}

Daha öncede belirtildiği üzere, görev kavramı öğrencilere verilen her türlü problem veya soru (Sáiz ve Figueras, 2009), karmaş1k durum/durumlar içeren problemler (Stein, Grover ve Henningsen, 1996) veya akıl yürütme becerilerini geliştiren her türlü problem veya sorular (Brousseau, 1997) olarak ifade edildiği için bu kısımdaki tartışma, problem ve problem kurma/oluşturma üzerinden de yapılacaktır. Bu bağlamda bu çalışmada, 18 öğretmenden her bir görev türü için ikişer görev olmak üzere her bir görev türü için toplam 36 görev oluşturmaları istenmiştir. Bu bağlamda, matematik öğretmenlerinin 3 görev türüne (model-bağlamsal-açık uçlu) yönelik görev oluşturma durumları incelendiğinde, katılımcıların her bir görev türü için en az \%72 oranında katılım göstererek görevler oluşturdukları belirlenmiştir. Katılımcılar tarafından oluşturulan görevlerin ilgili görev türü kapsamında değerlendirme oranları ise sırasıyla tür 1 (\%55), tür 2 (\%60), tür 3 (\%50) olarak tespit edilmiştir. Her bir görev türüne yönelik oluşturulan ve değerlendirmeye alınan görev türleri içerisinde, her bir görev türünün özelliklerinin en az \%70'ini sağlayan görevler incelendiğinde ise bu görevlerin 6'sının (\%50) modele dayalı görev, 6'nın (\%40) bağlama dayalı görev ve 8'nin (\%62) ise açık uçlu görev kapsamında olduğu belirlenmiştir. Her bir öğretmenden her bir görev türü için ikişer görev oluşturması istenmesine rağmen ilgili görev türlerine yönelik temel kodları ve bütün kodların en az \% 70'ni sağlayan görev sayısının (6-6-8) oldukça az olduğu dikkat çekmektedir. Bu durum, öğretmenlerin üç görev türüne yönelik görev oluşturmada genel anlamda istenilen düzeyde olmadıklarına işaret etmektedir. Benzer sonuçlar, farklı çalışmalarda da elde edilmiş ve öğretmen ya da öğretmen adaylarının farklı problemler türlerine yönelik sorular oluşturmada zorlandıkları ve hatalar yaptıkları belirlenmiştir (Dede ve Yaman, 2005; Köken ve Gökkurt-Özdemir, 2018; Stickles, 2006). Örneğin, Köken ve Gökkurt-Özdemir (2018) ortaokul matematik öğretmenleri ve ilköğretim matematik öğretmen adayları ile yürüttükleri çalışmada, katılımcıların çoğunun bir kavrama yönelik (prizmalar) problem kurma etkinliklerinde başarısız olduklarını tespit edilmiştir. Benzer şekilde Dede ve Yaman (2005)'ın çalışmasının sonuçları da, matematik öğretmeni adaylarının 
genellikle verilen problemleri çözdüklerini ancak bu problemlerden hareketle yeni problemler kuramadıklarını ortaya koymuştur. Yine ortaokul matematik öğretmenleri ve matematik öğretmen adaylarıyla yürütülen başka bir çalışmada ise katılımcıların iyi ifade edilmemiş problemler oluşturmalarına rağmen mantıklı problemler kurdukları belirlenmiştir. Aynı zamanda bu çalışmada, katılımcıların problem kurma sürecinde uygun yolları denemelerine rağmen başarısız olmalarının bir nedeni olarak problem kurma konusundaki mesleki eğitim eksiklikleri gösterilmiştir (Silver, Mamona-Downs, Leung ve Kenney, 1996). Diğer açıdan, problem kurma temalı çalışmalar incelendiğinde de problem kurmaya yönelik etkinlik ya da çalışmaların yapılmasının vurgulandığı görülmüş ve oluşturulan problemlerin kavramsal yönden eksikliklere sahip olduğu belirtilmiştir. (Ball, 1990; Örnek, 2020). Bu bağlamda, öğretmenlerin her bir görev türü için oluşturdukları görevlerin bir tartışması aşağıda sunulmuştur.

\section{Modele Dayalı Görevler}

Öğretmenlerin oluşturdukları ve değerlendirmeye alınan görevlerin \%55'inin bu görev türünde olduğu belirlenmiştir. Ancak bu modele ilişkin oluşturulan görevlerin, bu görevin kodlarının/özelliklerinin en az \%70'ni sağlama noktasında, - diğer iki görev türünde olduğu gibiistenilen düzeyde olmadığı belirlenmiştir. Zaten Sullivan vd. (2012) de, öğretmenlerin modele dayalı bir görevin oluşturulmasının ve bir görevin, model görev türüne ait olduğunun belirlenmesinin bu görev türü için yaşanılan en önemli zorluklar olduğunu ifade ettiklerini belirtmiştir. Kodların en az \%70'ini sağlamayan model görevlerin ise bu görev türüne ilişkin, model/temsil içerme ve kullanılan modellerin bilişsel bir destek olması vb. kodlarla eşleştiği fakat akıl yürütmeye teşvik etme, materyal kullanımını içerme, soyutlama yapma, birlikte çalışmayı gerektirme, etkinlik özelliği taşıma vb. özelliklerini daha az içerdiği görülmüştür. Ayrıca, öğretmenlerin matematik ders kitaplarından aşina oldukları tarzda, modele dayalı görev oluşturdukları da belirlenmiştir (örneğin, Ö8, Ö9). Bu durumun bir nedeni olarak, bazı matematik öğretmenlerinin (ve öğretmen adaylarının) matematiksel model ve matematiksel modellemeye yönelik genel bir bilgiye sahip olmalarına rağmen verilen örneklerden hangilerinin bir matematiksel model olarak nitelendirilebileceğine yönelik bilgilerinde bazı eksikliklerinin olması gösterilebilir (bkz. Dede, Akçakın ve Kaya, 2018; Işık ve Mercan, 2015; Urhan ve Dost, 2016).

\section{Bağlama Dayah Görevler}

Bağlama dayalı görevlerin, öğretmenlerin diğer iki görev türüne göre kısmen daha fazla değerlendirmeye alınan (\%60) görevler olduğu tespit edilmiştir. Bu sonucun, bağlama dayalı görev türünün "gerçek hayatla ilişkili olma" temel özelliğinden kaynaklandığı düşünülmektedir (bkz. Tablo 4). Üstelik MEB (2018) de, öğretmenlere matematiğin gerçek yaşamla ilişkilendirilerek 
öğretilmesini önermektedir. Ancak bu noktada dikkat çekici diğer bir sonuç, katılımcıların bağlama dayalı görev türüne yönelik oluşturdukları görevlerin genellikle hatalı, işlem becerisini geliştirmeye yönelik veya bir bağlama dayalı olma noktasında zayıf düzeyde kalmasıdır (ör. Ö7). Benzer şekilde Çomarlı (2018) da, öğretmenlerin problem kurarken kavramsal hatalar yaptıklarını ve genellikle basit işlemsel beceri gerektiren problemler üzerine yoğunlaştıklarını tespit etmiştir. Öğretmen adayları ile yapılan bazı çalışmalarda da benzer sonuçlar elde edilmiş ve öğretmen adaylarının kurdukları matematiksel problemlerin genellikle tahmin edilebilir, basit ve iyi yapılandırılmamış düzeyde kaldığı tespit edilmiştir (bkz. Crespo, 2003; Nicol, 1999; Stein vd., 2000). Diğer taraftan şimdiki çalışmada, öğretmenlerin gerçek yaşamla ilişkili bağlama dayalı görevler oluştururken daha çok sözel problemler oluşturma eğiliminde oldukları da tespit edilmiştir (ör., Ö8, Ö14). Sözel problemler, matematiksel yapısı oluşturulmuş bir görevin günlük hayata göre kısmen değiştirilerek yeniden ifade edilmesiyle elde edilen problemler olarak ifade edilmektedir. Ek olarak sözel problemler, bir problemin çözümüne ilişkin rutin çözüm yollarının kullanımını gerektirirken bağlama dayalı görevler ise tahmin etme, hesaplama, ölçme vb. rutin olmayan çözüm yollarını gerektirmektedir (bkz. Chapman, 2006). Dolayısıyla buradan öğretmenlerin kolay oluşturabilecekleri ve aşina oldukları problemleri (sözel problem) oluşturmaya eğilimli oldukları söylenebilir. Benzer şekilde Ho ve Hedberg (2005) da çalışmalarında, öğretmenlerin derslerinde genel olarak sözel ve standart problemler kullandıklarını belirlemiştir.

\section{Açık Uçlu Görevler}

Açık uçlu görev türünde oluşturulan görevler incelendiğinde, sadece 8'nin (\%62) bu görev türüne ilişkin kodların en az \%70'ni sağladığı belirlenmiştir. Öğretmenlerin bu görev türünü oluştururken zorlandıkları, açık uçlu göreve ilişkin temel özelliği/kodu (3.6 kodu) sağlayamadıkları, farklı şekillerde soru kalıpları kullanarak (ör. Ö9) açık uçlu görevler oluşturmaya çalıştıkları belirlenmiştir. Öğretmenlerin açı uçlu görevlerin inşasında zorlandıkları ve sinfflarında bu tür görevleri uygulama noktasında kaygı duydukları ilgili literatürde de not edilmektedir (bkz. Akay, Soybaş ve Argün, 2006). Ek olarak, bazı öğretmenlerin açık uçlu görevleri çoktan seçmeli sorular gibi gördükleri de gözlemlenmiştir (ör. Ö11). Bu sonuç, Çomarlı (2018)'in çalışmasının sonucu ile benzerlik göstermektedir. Bu durumun bir nedeni olarak, ülkemizde yapılan çoktan seçmeli merkezi sınavlar ve bu sınavların öğretmenler üzerindeki olası etkileri gösterilebilir.

\section{Matematiksel Görev Oluştururken Tercih Edilen Konular}

Matematik öğretmenlerinin matematiksel görev oluştururken tercih edilen konular her bir görev türü bağlamında ele alınmıştır. 


\section{Modele Dayalı Görevlerde Tercih Edilen Konular}

Öğretmenlerin görevleri oluştururken tercih ettikleri konular incelendiğinde, modele dayalı görev türünün kodlarının en az \%70'ini karşılayan görevlerin (6 görev), kesirler (2), eşitlik ve denge (1), cebirsel ifadeler (1), sayılar (1), üslü sayılar (1) konularında yoğunlaştığı görülmektedir. Öğretmenlerin model ile ilgili genel bir fikirleri olduğu görülmekle birlikte daha çok aşina oldukları modelleri kullandıkları (örneğin, sayı pullarıyla tamsayılarla toplama işlemi, kesirlerin modellenmesi vb.) tespit edilmiştir. Burada matematiksel konunun (ör. kesirler) özelliğinin model kullanımına uygunluğunun önemli olduğu görülmektedir. Model görev türünün kodlarının en az \%70'ini karşılamayan görevlerin (6 görev) ise cebirsel ifadeler (2), üçgende çevre hesaplama (1), katı cisimler (1), tamsayılar (1), üslü sayılar (1) konuları esas alınarak oluşturulmaya çalışıldığı da belirlenmiştir.

\section{Bağlama Dayah Görevlerde Tercih Edilen Konular}

Bağlama dayalı görev türüne ait kodların en az \%70'ini karşılayan görevlerin, (6 görev), sayı problemleri (1), ölçme (2), zaman hesaplama problemleri (1), üslü sayılar (1) ve oran (1) gibi matematiğin günlük hayatla ilişkisinin görülebileceği konularda yoğunlaştığı belirlenmiştir. Farklı bir çalışmada da, öğretmen adaylarının problemler için günlük yaşamda çok karşılaştıkları harçlık, diyet ve test çözme gibi sınırlı çeşitlilikte bağlamı tercih ettikleri belirlenmiştir (Ulusoy ve Kepceoğlu, 2018). Şimdiki çalışmada ise öğretmenlerin bağlama dayalı görev türüne yönelik görevler oluştururken matematiğin birçok farklı kavram ve konusunu tercih ettikleri belirlenmiştir. Fakat oluşturulan görevlerin çoğu, bağlama dayalı görev olma konusunda bazı eksiklikler (bağlama dayalı görevlere ilişkin temel özellikleri sağlamaması) içermesinden dolayı bu görev türüne yönelik görev kapsamında değerlendirilmemiştir.

\section{Açık Uçlu Görevlerde Tercih Edilen Konular}

Açık uçlu görev türünün kodlarının en az \%70' ini karşılayan görevlerin, görevlerin (8 görev), sayı problemleri (1), olasılık (1), bölme ve bölünebilme (1), sayılar (3), çarpanlarına ayırma (1) ve tamsayılar (1) gibi farklı matematik konuları esas alınarak oluşturulduğu belirlenmiştir. Sullivan ve arkadaşları (2012) da, matematik öğretmenlerinin açık uçlu görevler oluştururken sayılar, kesirler, hacim ve alan, sayı problemleri, çokgenler, üçgenler, çevre ve alan gibi matematiksel konulardan yararlandıklarını belirlemiştir (Sullivan vd., 2012). Bu sonuçlar şimdiki çalışmayla karşılaştırıldığında, her iki çalışmada da öğretmenler tarafından sayılar ve sayı problemleri konusunun ortak konular olarak seçildiği görülmektedir. Diğer taraftan, yukarıda verilen her bir görev türünün oluşturulmasında tercih edilen matematiksel konulara bakıldığında, kodların en az \%70'ini sağlayan görevler içerisinde, her üç görev türünde ortak seçilen bir matematiksel konunun bulunmadığı tespit edilmiştir. Fakat bazı konuların iki görev 
türünde de ortak olarak seçildiği görülmektedir. Örneğin; üslü sayılar, model ve bağlama dayalı görev türlerinde ele alınmıştır. Benzer şekilde; sayı problemleri, bağlama dayalı ve açık uçlu görev türlerinin, sayılar ise model ve açı uçlu görev türlerinin oluşturulmasında tercih edilmiştir.

Diğer taraftan, ilgili görev türüne ilişkin kodların en az \%70'ini karşılamayan veya bazı temel kodları sağlamadıklarından ilgili görev türü kapsamında değerlendirilmeyen görevler incelendiğinde ise her üç görev türünde ortak seçilen bir matematiksel konunun bulunmadığ1 tespit edilmiştir. Bunun yanında sayı problemlerinin ve kesirlerin, bağlama dayalı ve açık uçlu görev türü için tercih edildiği görülmüştür. Cebirsel ifadelerin ise model ve açık uçlu görev türlerinin oluşturulmasında tercih edildiği belirlenmiştir.

\section{SINIRLILIKLAR VE İLERİ ARAŞTIRMALAR}

$\mathrm{Bu}$ çalışma, 18 matematik öğretmeninin kendilerine yöneltilen bir açık uçlu soruya verdikleri cevapların analiziyle sınırı bir durum çalışmadır. Bu nedenle bu çalışmanın sonuçları, daha büyük örneklemler üzerinden gerçekleştirilecek nicel desenli çalışmalarla test edilebilir. Ayrıca, şimdiki çalışmada elde edilen bulguların altında yatan olası nedenlerin belirlenmesi için öğretmenlerle mülakat ve sınıf içi gözlemleri de içeren ileri nitel çalışmalar da yapılabilir. Bu anlamda, şimdiki çalışmanın sonuçlarının bu tür ileri çalışmalar için iyi bir başlangıç noktası olabileceği düşünülmektedir. Diğer taraftan bu çalışmanın sonuçları, matematik öğretmenlerinin incelenen üç matematiksel görev türü için de görev oluşturmada genel anlamda başarılı olamadıklarını ortaya koymaktadır. Halbuki matematiksel kavramların gerçek yaşamla ilişkilendirilme süreci ve uluslararası karşılaştırmalı araştırmaların (ör., Uluslararası Öğrenci Değerlendirme Programı-The Program for International Student Assessment [PISA]) ölçmeye çalıştığı matematiksel beceriler düşünüldüğünde (bkz. Ekonomik İşbirliği ve Kalkınma Örgütü Organization for Economic Co-operation and Development [OECD], 2016), bu tür matematiksel görevlerin (özellikle bağlama dayalı ve açık uçlu görevler) ne kadar önemli oldukları görülebilir. Bu nedenle burada, öğretmenlerin farklı görev türlerine yönelik görevler oluşturmadaki bilgi ve becerilerinin gelişiminin desteklenmesi, bu olumsuz durumun giderilmesi ve bunların altında yatan olası faktörlerin belirlenmesine yönelik ileri araştırmaların yapılmasının önemi ortaya çıkmaktadır. Araştırmada elde edilen diğer bir sonuç ise oluşturulan matematiksel görevlerin özelliklerinin öğretmenler tarafından tam olarak anlaşılamadığıdır. Zira bazı öğretmenlerin mevcut sınav sistemindeki çoktan seçmeli soruları açık uçlu görev olarak değerlendirildiği göz önüne alındığında, öğretmenlerin aşina oldukları soru ve problemlerin dışındaki görev türlerine yönelik farkındalıklarının da artmasının hem mesleki gelişimleri hem de matematiğin öğretim ortam ve süreçlerinin etkililiği için önemli olduğu düşünülmektedir. Son olarak, öğretmenlerin matematiksel görevleri oluştururken tercih ettikleri matematiksel kavram ve konuları niçin tercih 
ettiklerinin (ör. sayılar) ve bunun altında yatan olası nedenlerin belirlenmesi de ileri araştırmalar için burada önerilebilir. Ayrıca bu anlamda, bu çalışmanın sonuçlarının ileri araştırmalar için iyi bir zemin oluşturabileceği de düşünülmektedir.

\section{KAYNAKÇA}

Akay, H., Soybaş, D., \& Argün, Z. (2006) Problem kurma deneyimleri ve matematik öğretiminde açı uçlu soruların kullanımı. Kastamonu Eğitim Dergisi, 14(1), 129-146.

Anthony, G., \& Walshaw, M. (2009). Effective pedagogy in mathematics. Educational series 19. Brussels: International Academy of Education; Geneva: International Bureau of Education.

Ball, D. L. (1990). The mathematical understandings that prospective teachers bring to teacher education. The Elementary School Journal, 90(4), 449-466.

Benckert, S. (1997). Context and conversation in physics education. http:/ /www.nshu.se/download /3018/benckert_sylvia_97.pdf sayfasından erişilmiştir.

Brousseau, G. (1997). Theory of didacticel situations in mathematics (Didactiques des Mathe' matiques) 1970-1990. Dordrecht: Kluwer (Translated by Balachheff, N., Cooper, M., Sutherland, R., ve Warfield, V.).

Chapman, O. (2006). Classroom practices for context of mathematics word problems. Educational Studies in Mathematics, 62, 211-230.

Clarke, D. M. (1997). The changing role of the mathematics teacher. Journal for Research in Mathematics Education, 28(3), 278-308.

Clarke, D., \& Roche, A. (2010). Teachers' extent of the use of particular task types in mathematics and choices behind that use. Mathematics Education Research Group of Australasia.

Cohen, L., Manion, L., \& Morrison, K. (2000). Research methods in education (5th eds.). London: Routledge Falmer.

Crespo, S. (2003). Learning to pose mathematical problems: Exploring changes in preservice teachers' practices. Educational Studies in Mathematics, 52, 243-270.

Creswell, J. W. (1998). Qualitative inquiry and research design: Choosing among five traditions. Thousand Oaks, CA: Sage.

Creswell, J. W. (2012). Research design: Qualitative, quantitative, and mixed methods approaches (4th Ed.). London: SAGE Publications.

Creswell, J. W. (2013). Qualitative inquiry \& research design choosing among five approaches (3rd Ed.). Thousand Oaks, CA SAGE Publications.

Cumhur, Ö. Ü. F., Çavdar, Ö. Ü. O., \& Polat, A. G. S. (2018). Matematik ve fen bilimleri öğretmeni adaylarının bloom taksonomisi'ne göre oluşturdukları soruların değerlendirilmesi. Journal of Social and Humanities Sciences Research (Jshsr), 5(28), 3243-3252.

Çomarlı, S. K. (2018). Ortaokul matematik öğretmenlerinin veri işleme öğrenme alanına ilişkin problem kurma becerilerinin incelenmesi. Yüksek Lisans Tezi, Bartın Üniversitesi, Bartın. 
Dede, Y., Akçakın, V., \& Kaya, G. (2018). Ortaokul matematik öğretmen adaylarının matematiksel modelleme yeterliklerinin cinsiyete göre incelenmesi: çok boyutlu madde tepki kuramı. Adıyaman Üniversitesi Eğitim Bilimleri Dergisi 8, 150-169.

Dede, Y., \& Yaman, S. (2005). Matematik öğretmen adaylarının matematiksel problem kurma ve problem çözme becerilerinin belirlenmesi. Eğitim Araştırmaları Dergisi, 5(18), 41- 56.

Doyle, W. (1983) Academic work. Review of Educational Research, 53, 159-199.

Fullan, M. (2001). The new meaning of educational change (3. Baskı). New York: Teachers College Press.

Henningsen, M., and Stein, M. K. (1997). Mathematical tasks and student cognition: Classroombased factors that support and inhibit high-level mathematical thinking and reasoning. Journal for Research in Mathematics Education, 28, 524-549.

Hiebert, J., \& Carpenter, T. P. (1992). Learning and teaching with understanding. In D. A. Grouws (Eds.), Handbook of research on mathematics teaching and learning (pp. 65-97). New York: Macmillan.

Hiebert, J., Carpenter, T. P., Fennema, E., Fuson, K. C., Wearne, D., Murray, H., et al. (1997). Making sense: Teaching and learning mathematics with understanding. Portsmouth, NH: Heinemann.

Hiebert, J., \& Wearne, D. (1993). Instructional tasks, classroom discourse, and students' learning in second-grade arithmetic. American Educational Research Journal, 30(2), 393-425.

Ho, F. K., \& Hedberg, G. J. (2005). Teachers' pedagogies and their impact on students' mathematical problem solving. Journal of Mathematical Behavior, 238-252.

Işık, A., \& Mercan, E. (2015). Ortaokul matematik öğretmenlerinin model ve modelleme hakkındaki görüşlerinin incelenmesi. Kastamonu Ĕ̆itim Dergisi, 23(4), 1835-1850.

Krainer, K. (1993). Powerful tasks: A contribution to a high level of acting and reflecting in mathematics instruction. Educational Studies in Mathematics, 24(1), 65-93.

Köken, C. B., \& Gökkurt-Özdemir, B. (2018). Öğretmenlerin ve öğretmen adaylarının farklı problem kurma durumlarına ilişkin performanslarının incelenmesi: prizma örneği. II. Uluslararası Sınırsız Eğitim ve Araştırma Sempozyumu, Muğla: Bodrum.

Lincoln, Y. S., \& Guba, E. G. (1985). Naturalistic inquiry. Newburry Park, CA: Sage.

Lindquist, M. M., \& Kouba, V. L. (1989). Measurement. In M. M. Lindquist (Eds.), the National Assessment of Educational Progress (pp. 35-43). Reston, VA: National Council of Teachers of Mathematics.

Macnealy, M. (1999). Strategies for empirical research in writing. New York, NY: Longman.

Marx., R., Walsh, J. (1988). Learning from academic tasks. The Elementary School Journal, 88(3), 207219. 
Merriam, S. B. (2013). Qualitative research a guide to design and implementation. John Wiley \& Sons Inc., New York.

Miles, M. B., \& Huberman, A. M. (1994). Qualitative data analysis: An expanded sourcebook. New York: Sage.

Milli Eğitim Bakanlığı (MEB). (2005). İlköğretim matematik dersi öğretim programı ve klavuzu: 1 ve 5. sinıflar. Ankara, Devlet Kitapları Müdürlüğü.

Milli Eğitim Bakanlığı (MEB). (2018). Ortaöğretim matematik dersi öğretim programı. Ankara.

National Council of Teachers of Mathematics [NCTM]. (1989). Curriculum and evaluation standards for school mathematics. Reston, VA: Author.

National Council of Teachers of Mathematics [NCTM]. (1991). Professional standards for teaching mathematics. Reston, VA: Author.

National Council of Teachers of Mathematics [NCTM]. (1995). Assessment standards for school mathematics. Reston, VA: Author.

National Council of Teachers of Mathematics [NCTM]. (2000). Principles and standards for school mathematics. Reston: National Council of Teachers of Mathematics.

National Research Council. (1989). Everybody counts. Washington, DC: National Academy Press.

Norton, A., \& Kastberg, S. (2012). Learning to pose cognitively demanding tasks through letter writing. Journal of Mathematics Teacher Education, 15(2), 109-130.

Organisation for Economic Co-operation and Development. (2016). PISA 2015 results (Volume I): Excellence and equity in education. Paris, France: Author.

Örnek, T. (2020). Problem kurma becerisini geliştirmek için tasarlanan problem kurma öğrenme modeli'nin değerlendirilmesi. Yayınlanmamış Doktora Tezi, Yükseköğretim Kurulu Ulusal Tez Merkezi'nden edinilmiştir. (624464)

Redfield, D. L., \& Rousseau, E.W. (1991). A meta-analysis of experimental research on teacher questioning behavior. Review of Educational Research, 51, 237-245.

Sáiz, M., \& Figueras, O. (2009). A research-based workshop design for volume tasks. In Tasks in primary mathematics teacher education (pp. 147-160). Springer, Boston, MA.

Schoenfeld, A. H. (1992). Learning to think mathematically: Problem solving, metacognition, and sense making in mathematics. In D. A. Grouws (Eds.), Handbook of Research on Mathematics Teaching and Learning (pp. 334-371). New York: Macmillan.

Schoenfeld, A. H. (1994). Reflections on doing and teaching mathematics. In A. H. Mathematical thinking and problem solving (pp. 53-70). Hillsdale, NJ: Erlbaum.

Silver, E. A., \& Herbst, P. G. (2008). Theory in mathematics education scholarship. In F. K. Lester (Eds.), Second handbook of research on mathematics teaching and learning (pp. 39-68). Charlotte, NC: Information Age Publishing. 
Silver, E. A., Mamona-Downs, J., Leung, S., \& Kenny, P. A. (1996). Posing mathematical problems in a complex environment: An exploratory study. Journal for Research in Mathematics Education, 27(3), 293-309.

Smith, M. S., \& Stein, M. K. (1998). Selecting and creating mathematical tasks: From research practice. Mathematics teaching in the middle school, 3(5), 344-50.

Stein, M. K., Grover, B. W., \& Henningsen, M. (1996). Building student capacity for mathematical thinking and reasoning: Analysis of mathematical tasks used in reform classrooms. American Educational Research Journal, 33, 455- 488.

Stein, M. K., \& Lane, S. (1996). Instructional tasks and the development of student capacity to think and reason: An analysis of the relationship between teaching and learning in a reform mathematics project. Educational Research and Evaluation, 2(1), 50-80.

Stein, M. K., \& Smith, M. S. (1998). Mathematical tasks as a framework for reflection. Mathematics Teaching in the Middle School, 3, 268-275.

Stein, M. K., Smith, M. S., Henningsen, M., \& Silver, E. A. (2000). Implementing standartsbased mathematics instruction: A casebook for professional development. New York: Teachers College Press.

Stickles, P. R., (2006). An analysis of secondary and middle school teacher's mathematical problem posing. Indiana University.

Sullivan, P., Clarke, D., \& Clarke, B. (2012). Teaching with tasks for effective mathematics learning (vol. 9). Springer Science \& Business Media.

Sullivan, P., Clarke, D. M., Clarke, B. A., \& O'Shea, H. (2009). Exploring the relationship between tasks, teacher actions, and student learning. In M. Tzekaki, M. Kaldrimidou, \& H. Sakonidis (Eds.), In search of theories in mathematics education (Proceedings of the 33rd Conference of the International Group of Psychology of Mathematics Education, 5, 185192.

Swan, M. (2005). Improving learning in mathematics: Challenges and strategies. London: Department for Education and Skills Standards Unit.

Tavşancıl, E., \& Aslan, A. E. (2001). Sözel, yazılı ve diğer materyaller için içerik analizi ve uygulama örnekleri. İstanbul: Epsilon Yayınları.

Türk Dil Kurumu. (2011). Türkçe sözlük. Ankara: TDK.

Türnüklü, E., Aydoğdu, M. Z., \& Ergin, A. S. (2017). 8. sinıf öğrencilerinin üçgenler konusunda problem kurma çalışmalarının incelenmesi. Bayburt Ĕ̆itim Fakültesi Dergisi, 12(24), 467486.

Tyminski, A. M., Land, T. J., Drake, C., Zambak, V. S., \& Simpson, A. (2014). Preservice elementary mathematics teachers' emerging ability to write problems to build on 
children's mathematics. In Research trends in mathematics teacher education (pp. 193-218). Springer, Cham.

Tzur, R., Zaslavsky, O., \& Sullivan, P. (2008). Examining teachers' use of (non-routine) mathematical tasks in classrooms from three complementary perspectives: Teacher, teacher educator, researcher. In O. Figuras, J. L. Cortina, S. Alatorre, T. Rojano, \& A. Sepulveda (Eds.), Proceedings of the 32nd Annual Conference of the International Group for the Psychology of Mathematics Education, 1, 121-123.

Ulusoy, F., \& Kepceoğlu, İ. (2018). İlköğretim matematik öğretmen adaylarının yarıyapılandırılmış problem kurma bağlamında oluşturdukları problemlerin bağlamsal ve bilişsel yapısı. Kırşehir Eğitim Fakültesi Dergisi, 19(3), 1910-1936.

Urhan, S., \& Dost, Ş. (2016). Matematiksel modelleme etkinliklerinin derslerde kullanımı: öğretmen görüşleri. Elektronik Sosyal Bilimler Dergisi, 15(59), 1279-1295.

Van de Walle, J. A., Karp, K. S., Bay-Williams, J. M., Wray, J., \& Brown, E. T. (2019). Elementary and middle school mathematics: Teaching developmentally (10th ed.). New York, NY: Pearson Education Inc.

Yeo, J. B. (2007). Mathematical tasks: Clarification, classification and choice of suitable tasks for different types of learning and assessment. (Tech. Rep. ME2007-01). National Institute of Education, Nanyang Technological University, Singapore.

Yun-peng, M., Chi-chung, L., \& Ngai-ying, W., (2006). Chinese primary school mathematics teachers working in a centralised curriculum system: a case study of two primary schools in north-east china. Compare, 36(2), 197-212.

Zaslavsky, O. (2005). Seizing the opportunity to create uncertainty in learning mathematics. Educational Studies in Mathematics, 60, 297-321.

Winne, P.H. (1979). 'Experiments relating teacher' use of higher cognitive questions to student achivement. Review o Educational Researc. 49, 13-50. 
Gazi Eğitim Bilimleri Dergisi (GEBD) Gazi Journal of Education Sciences (GJES)

EK 1.

Tablo 4.

Matematiksel Görev Türleri Ve Özellikleri/Kodlarn

\begin{tabular}{|c|c|c|}
\hline $\begin{array}{l}\text { Görev } \\
\text { Türleri }\end{array}$ & Özellikler/Kodlar & Örnek \\
\hline 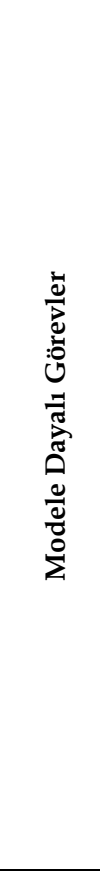 & 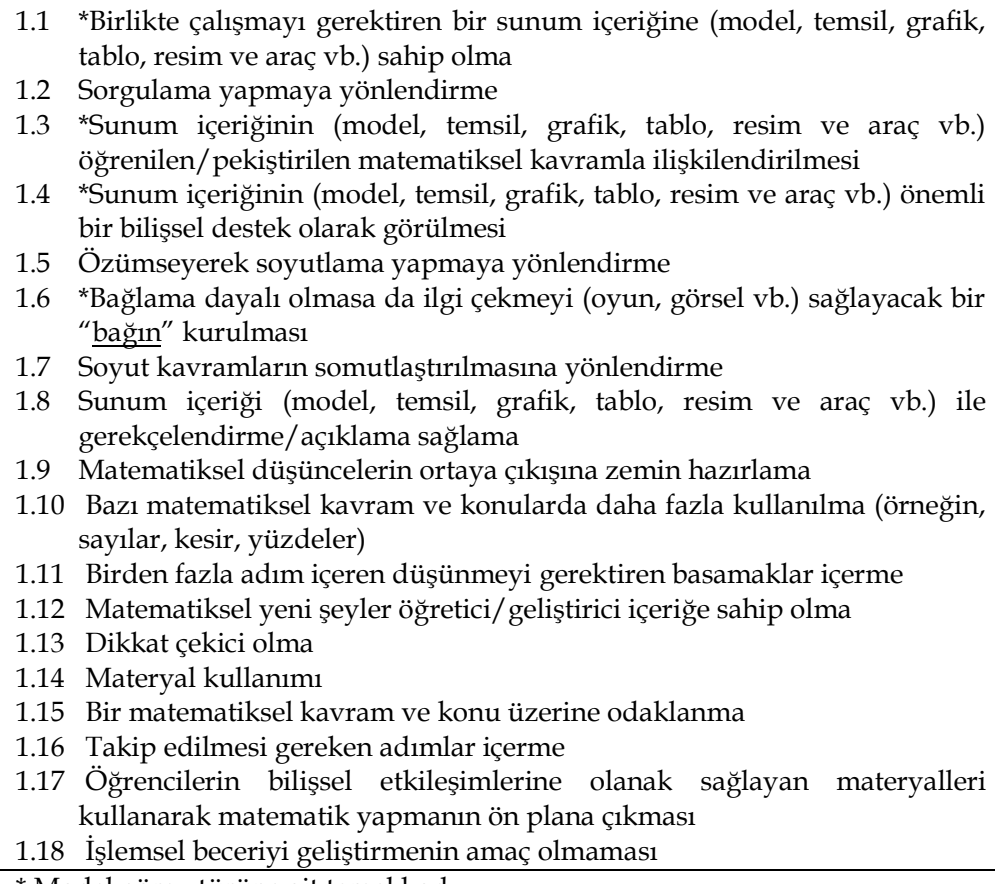 & $\begin{array}{l}\text { - } \quad \text { Kesirler oluşturacak şekilde numaralı kartları }(1,3,4,5,6,7) \text { kutulara yerleştiriniz. } \\
\text { - } \quad \text { Her kartın sadece bir kez kullanılma hakkı vardır. } \\
\text { düzan kesirlerin toplamı, mümkün olduğu kadar 1'e yakın ama } 1 \text { olmayacak şekilde } \\
\text { Görevin içerdiği özellikler ve kodlar: } \\
1.1,1.2,1.3,1.4,1.5,1.6,1.8,1.9,1.10,1.11,1.12,1.13,1.14,1.15,1.16,1.17,1.18\end{array}$ \\
\hline
\end{tabular}

Polat, S., \& Dede, Y. (2020). Matematik öğretmenlerinin matematiksel görev oluşturma durumlarının incelenmesi. Gazi Eğitim Bilimleri Dergisi, 6(2), 210239. DOI: https://dx.doi.org/110.30855/gjes.2020.06.02.003

Dergi Web Sayfası: http://dergipark.gov.tr/gebd 
Tablo 4.

\begin{tabular}{|c|c|c|}
\hline \multirow[t]{2}{*}{ 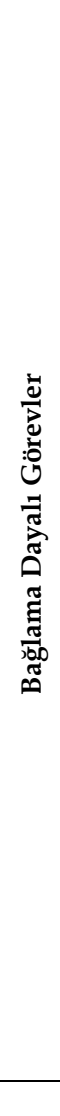 } & 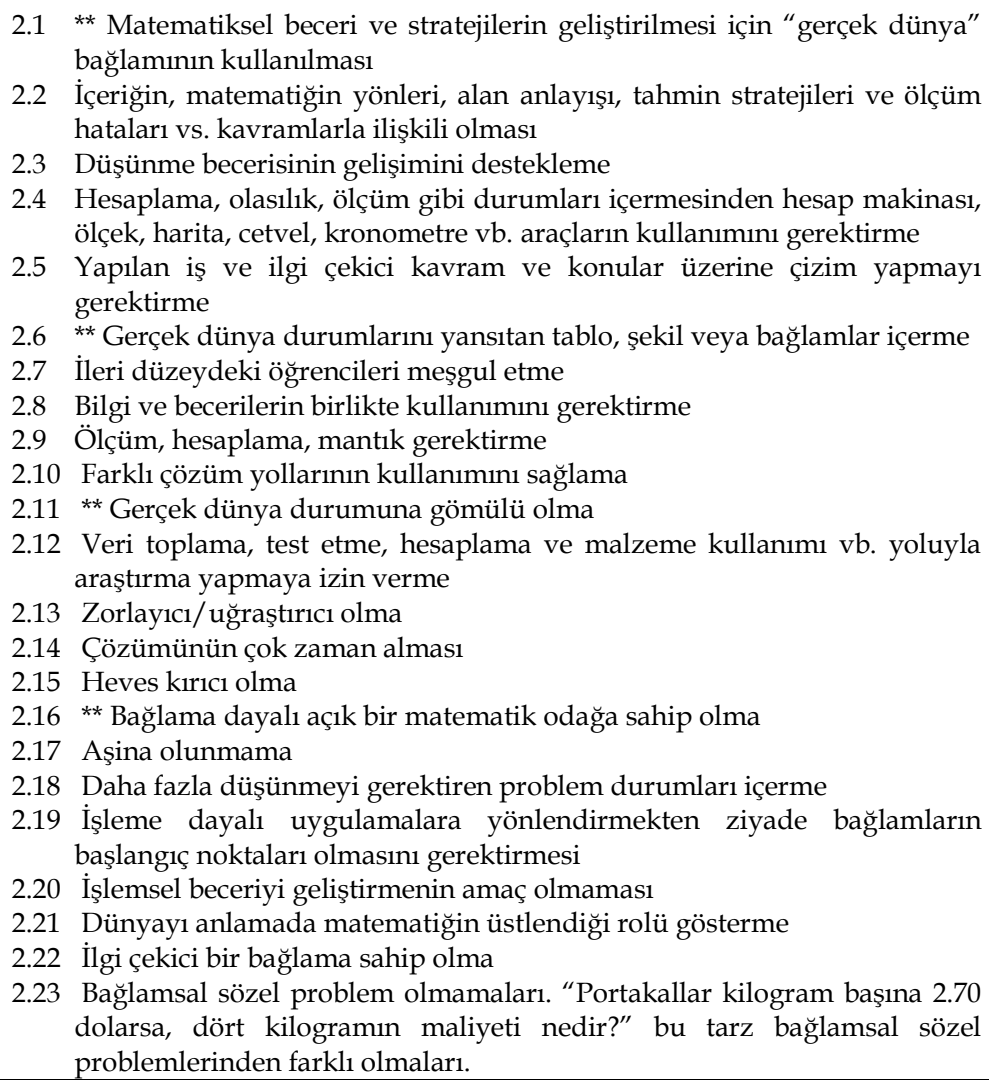 & $\begin{array}{l}\text { - Yukarıda, bir şehrin diğer } 14 \text { şehre uzaklı̆̆ını gösteren tablo verilmiştir. } \\
\text { - } \quad \text { İkşerli gruplar halinde çalışarak tabelanın yerini bulunuz. } \\
\text { - } \quad \text { Görev, fotoğrafın nerede çekildiğini tahmin etmeye dayalıdır. } \\
\text { - } \quad \text { Örneğin, Sydney'den 2,159 km uzaklıkta olabilecek tüm olası şehirlerle ilgili olarak, tahmin } \\
\text { etme, ölçek kullanma, olasılık ve konuma vb. dair fikirlerin oluşturulmasına yönelik bir } \\
\text { görevdir. }\end{array}$ \\
\hline & ** Bağlama dayalı görev türüne ait temel kod & \\
\hline
\end{tabular}


Tablo 4.

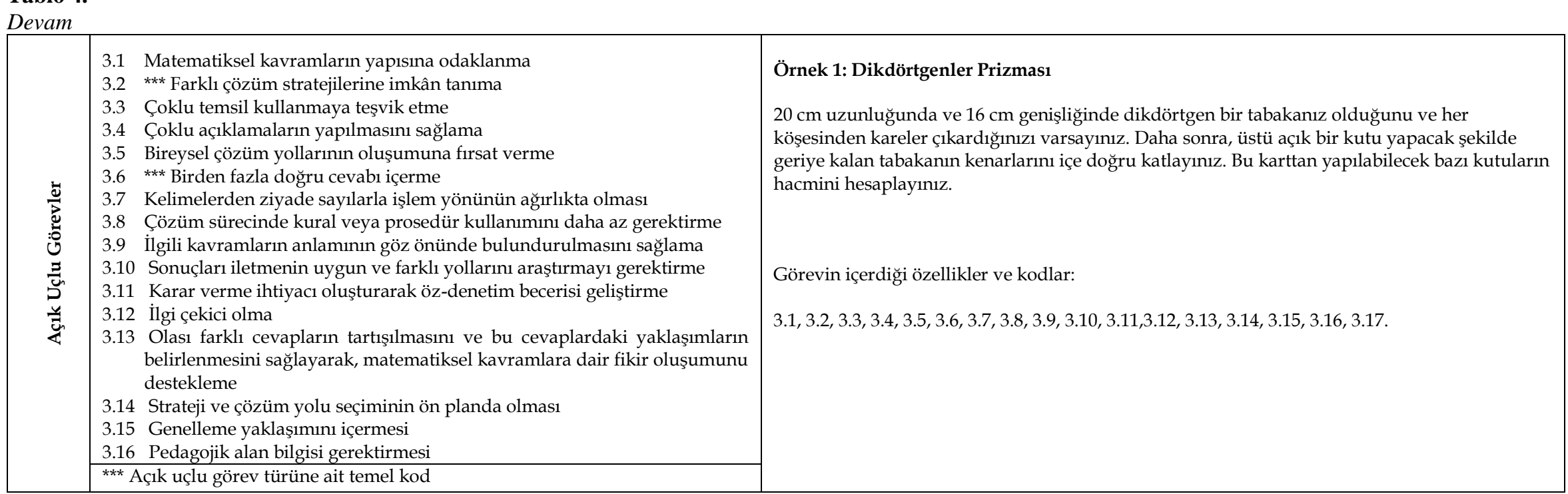

